\title{
Can Capital Income Taxes Survive? And Should They?
}

Sørensen, Peter Birch

Publication date:

2006

Document version

Publisher's PDF, also known as Version of record

Citation for published version (APA):

Sørensen, P. B. (2006). Can Capital Income Taxes Survive? And Should They? Economic Policy Research Unit. Department of Economics, University of Copenhagen. http://www.econ.ku.dk/eprn_epru/Workings_Papers/wp06-06.pdf 


\section{EPRU Working Paper Series}

Economic Policy Research Unit

Department of Economics

University of Copenhagen

Studiestræde 6

DK-1455 Copenhagen $K$

DENMARK

Tel: (+45) 35324411

Fax: (+45) 35324444

Web: http://www.econ.ku.dk/epru/

Can Capital Income Taxes Survive? And Should They?

Peter Birch Sørensen

2006-06

ISSN 0908-7745

The activities of EPRU are financed by a grant from

The National Research Foundation 
August 2006

Second draft

\title{
CAN CAPITAL INCOME TAXES SURVIVE? AND SHOULD THEY?
}

\author{
By Peter Birch Sørensen \\ University of Copenhagen, EPRU and CESifo \\ Revised version of keynote lecture presented at the \\ CESifo Venice Summer Institute workshop on \\ The Future of Capital Income Taxation \\ at Venice International University, 17-18 July 2006
}

\begin{abstract}
The paper surveys some main results in the theory of capital income taxation in the open economy; reviews recent trends in international taxation, and discusses alternative blueprints for fundamental capital income tax reform from the perspective of an open economy faced with growing mobility of capital income tax bases.
\end{abstract}

Address for correspondence:

Peter Birch Sørensen

Department of Economics, University of Copenhagen

Studiestraede 6, 1455 Copenhagen K, Denmark

E-mail: peter.birch.sorensen@econ.ku.dk 


\title{
Can Capital Income Taxes Survive? And Should They?
}

\author{
Peter Birch Sørensen ${ }^{1}$
}

\section{Introduction}

Can capital income taxes survive? And should they? In recent recent decades these questions have been debated with increasing intensity among tax economists and policy makers, as growing capital mobility and the ensuing tax competition has driven down statutory tax rates on capital income throughout the world. Those who believe that returns to savings should not be taxed have typically welcomed capital tax competition, hoping that it will push governments towards greater reliance on consumption-based taxation. However, many other observers fear that an erosion of capital income taxation will undermine the integrity and political legimitacy of the tax system and lead to greater inequality and to an underprovision of public goods - the well-known spectacle of a 'race to the bottom'.

In this paper I discuss whether capital income taxes are actually vanishing, and whether and how we should attempt to tax capital income in a globalising economy. These are big issues, so my discussion will have to be selective. Throughout the paper I will focus on tax policy in the open economy, but I will not address the problem of international tax coordination. Instead, I will ask how the national government of an open economy can and should design its system of capital income taxation, taking the policies of other countries as given, and assuming that extensive multilateral agreements on tax coordination are not politically feasible at the present stage of international political integration. ${ }^{2}$

The paper falls in three parts. Part 1 presents some theory and evidence on capital income taxation in the open economy. Part 2 discusses alternative blueprints for capital income tax reform in a globalising economy, and Part 3 summarizes and compares the main reform options.

\footnotetext{
${ }^{1}$ I thank participants in the 2006 CESifo Venice Summer Institute for comments on a previous version of this paper. Parts of the paper draw on joint work with Michael P. Devereux (Devereux and Sørensen, 2005). I am very grateful to him; he bears no responsibility for any errors.

${ }^{2}$ In Sørensen (2000, 2001, 2004a and 2004b) I have discussed various aspects of international tax coordination.
} 


\section{PART 1. CAPITAL INCOME TAXATION IN THE OPEN ECONOMY: THEORY AND SOME EVIDENCE}

\subsection{Taxing capital income - some basic distinctions}

\subsubsection{Taxes on saving versus taxes on investment}

Capital income takes many forms such as interest, dividends, capital gains, business profits, the value of the housing services enjoyed by owner-occupiers, etc. Some types of capital income are harder to tax than others, technically and politically, so in practice capital income tax systems tend to be highly complex, incoherent and discriminatory. I shall return to this problem later on. For the moment, I will focus on some basic theoretical distinctions which are fundamental for understanding the effects of capital income taxes.

The first distinction is that between source-based and residence-based taxes on capital. Under the source principle (the return to) capital is taxed only in the country where it is invested. Source-based taxes may therefore be termed taxes on investment. Under the residence principle the tax is levied only on (the return to) the wealth owned by domestic residents, regardless of whether the wealth is invested at home or abroad. Since wealth is accumulated saving, residence-based taxes may also be termed taxes on saving.

The most important example of a source-based capital tax is the corporate income tax, since most countries only tax corporate income generated within their borders. ${ }^{3}$ In contrast, the personal income tax as well as the personal wealth tax are based on the residence principle, since domestic residents are liable to tax on their worldwide capital income and on wealth invested abroad as well as at home. As a rough approximation, we may therefore say that the corporation tax is a tax on investment, whereas the personal taxes on capital income and wealth are taxes on saving.

In an open economy with free international mobility of capital, the two types of taxes have very different effects on the domestic economy and on international capital flows. ${ }^{4}$ This is illustrated in Figure 1 where the horizontal axis measures the volumes of domestic saving and investment, while the vertical axis measures the real rates of return on saving and investment. The downward-sloping curve labelled ' $I$ ' indicates how the level of domestic investment varies with the

\footnotetext{
${ }^{3}$ Some countries like the United States also levy domestic corporation tax on the profits that their multinational companies repatriate from abroad, but only to the extent that the domestic corporate tax exceeds the foreign corporation tax which has already been paid in the foreign source country. Moreover, in practice most of the profits earned by the foreign affiliates of multinational companies tend to be retained and reinvested in the host (source) country in which case the profit is taxed only in that country. As a first approximation, it is therefore fair to say that corporate income is taxed according to the source principle.

${ }^{4}$ For a formal treatment of this issue, stressing the implications for attempts to integrate the corporate and the personal income tax, see Boadway and Bruce (1992) and Fuest and Huber (2000).
} 
required pre-tax rate of return. The lower is the required return, the greater is the volume of investment which will be deemed profitable. The upward-sloping curve denoted by ' $S$ ' shows how the level of domestic saving varies with the after-tax rate of return. The positive slope of this curve reflects the common assumption that a higher after-tax return will induce a higher volume of saving.

The horizontal curve labelled ' $r$ ' measures the cost of finance to domestic corporations. This is the rate of return that the investors providing the finance require after payment of corporation tax but before payment of any personal tax. If we consider a corporate investment financed by equity, then $r$ is the required return on shares before payment of personal taxes on wealth and on dividends and capital gains on shares. If the investment is instead financed by debt, $r$ is the rate of interest before personal taxes on interest and wealth. In Figure 1 the corporation tax is denoted by $t_{I}$, so a corporate investment has to earn a minimum return $r^{g}=r+t_{I}$ to cover the corporation tax bill as well as the cost of finance. Hence the level of domestic corporate investment is given by $I^{e}$. Furthermore, when domestic personal taxes (denoted by $t_{S}$ ) are deducted from the return $r$ offered in the markets for shares and interest-bearing assets, domestic savers end up with an after-tax return equal to $r^{n}$, so the level of domestic saving becomes $S^{e}$. The excess of domestic investment over domestic saving has to be financed by capital imports from abroad, so in the example given in Figure 1 the volume of capital imports is given by the distance $I^{e}-S^{e}$.

In an open economy where investors can invest in foreign as well as domestic securities, the cost of finance $r$ is given by the rate of return required in the international capital market. When the domestic economy is small, it does not have any noticeable impact on the international interest rate or the rate of return on shares required by international investors. Hence the level of $r$ may be taken as given from the viewpoint of the small open economy. This means that personal taxes on saving do not have any impact on domestic investment. In Figure 1 a rise in the savings tax $t_{S}$ implies a movement down along the $S$-curve, leading to a lower volume of domestic saving and a higher level of capital imports without affecting domestic investment. In contrast, a rise in the investment tax $t_{I}$ reduces the level of domestic investment and leads to lower capital imports but does not affect domestic saving. 


\section{Figure 1: Taxes on saving versus taxes on investment in a small open economy}

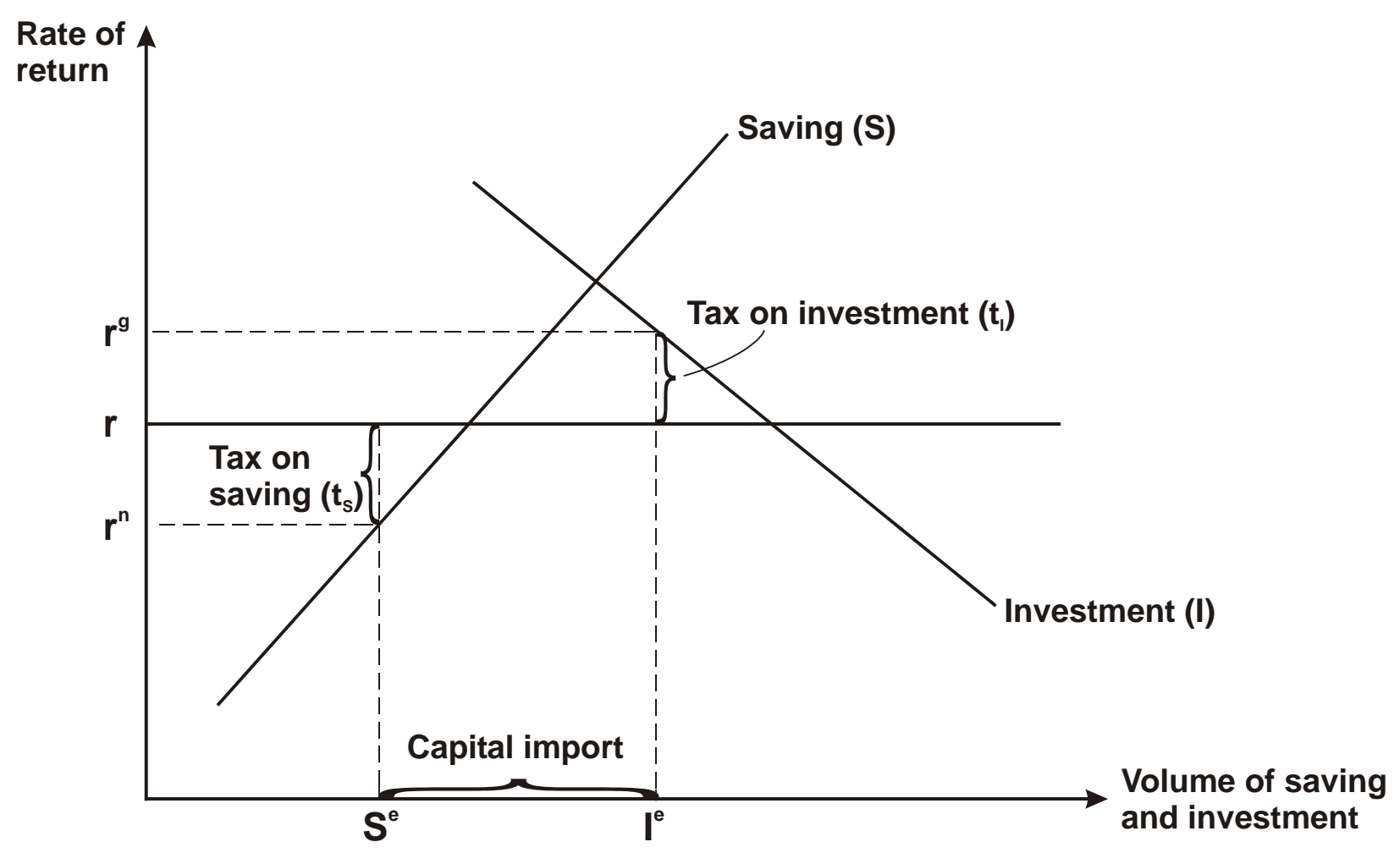

This analysis has important implications for tax policy. In particular, it shows that if the government of a small open economy wishes to stimulate domestic real investment through lower taxes on capital, it should concentrate on lowering source-based taxes on investment such as the corporation tax. According to Figure 1, a lowering of savings taxes such as the personal taxes on dividends and capital gains on shares will not stimulate domestic investment. Rather, it will stimulate domestic saving and will most likely imply that some shares in domestic companies that were previously owned by foreign investors will be taken over by domestic investors, thus increasing the share of the domestic business sector controlled by domestic owners.

We should mention two important qualifications to the simplified analysis in Figure 1. First of all, although the personal tax on income and wealth is formally based on the residence principle, in practice it is often very difficult for the domestic tax authorities to monitor (the return to) a taxpayer's personal wealth invested abroad, as discussed in section 1.5 below. For this reason even personal taxes on capital may in reality end up falling mainly on capital invested at home, as would be the case if the source principle were applied.

Second, the analysis in Figure 1 assumes that shares in domestic unquoted companies are perfect substitutes for shares which are traded in the international stock market so that the cost 
of finance for small domestic unquoted companies is effectively determined in the international stock market. In practice the shares in domestic unquoted companies will tend to be imperfect substitutes for the shares of the large quoted companies, because the two types of shares will have different risk characteristics. In these circumstances domestic taxes on dividends and capital gains will have some effect on the cost of finance for small domestic companies which are not quoted in the stock exchange. ${ }^{5}$

For both of these reasons a lowering of personal taxes on capital could have some positive influence on domestic investment, but the conclusion remains that the most powerful capital tax instrument to affect investment is a genuine source-based tax like the corporate income tax. Much of the discussion below will therefore concentrate on the corporation tax.

\subsubsection{Taxes on normal returns versus taxes on rents}

The second fundamental distinction in the theory of capital income taxation is the one between taxes on the normal return to capital and taxes on rents. By definition, rents are 'pure profits' in excess of the going market of return on capital. For debt capital, the normal return is the market rate of interest on debt in the relevant risk class, and for equity it is the required market rate of return on stocks with the relevant risk characteristics. If markets for risk pooling are underdeveloped, the required risk premia will tend to be higher, and so will the normal return.

In a closed economy a tax on the normal return to capital will tend to reduce the volume of saving and investment (if the elasticity of saving with respect to the net return is positive) whereas a tax on pure rents will be non-distortionary. However, in the open economy a sourcebased tax on rents will reduce domestic investment if the business activity generating the rent is internationally mobile, that is, if the firm is able to earn a similar excess return on investment in other countries. In that case we may speak of firm-specific or mobile rents. In other words, when the economy is open, a source-based tax will be non-distortionary only if it falls on location-specific (that is, immobile) rents. Location-specific rents may be generated by the exploitation of natural resources, by the presence of an attractive infrastructure, or by agglomeration forces (see section 1.3.2 below), whereas firm-specific rents may arise from the possession of a specific technology, product brand or management know-how.

\footnotetext{
${ }^{5}$ For a formal analysis of this issue, see Sørensen (2005c)
} 


\subsubsection{A fundamental proposition on capital income taxation in the open economy}

A fundamental theorem - originally derived by Gordon (1986) and forcefully restated by Razin and Sadka (1991) - states that in the absence of location-specific rents, a small open economy should not levy any source-based taxes on capital. ${ }^{6}$ Under perfect capital mobility a small open economy faces a perfectly elastic supply of capital from abroad, so the burden of a sourcebased capital tax will be fully shifted onto workers and other immobile domestic factors via an outflow of capital which drives up the pre-tax return. In this process, the productivity of the domestic immobile factors will fall due to a lower capital intensity of production. To avoid this drop in productivity, it is more efficient to tax the immobile factors directly rather than indirectly via the capital tax.

If governments pursue optimal tax policies, we should therefore expect to observe a gradual erosion of source-based capital income taxes in the recent decades marked by growing capital mobility. Is this actually happening?

\subsection{Trends in corporate income taxation: a puzzle}

To answer this question, let us look at the most important source-based capital income tax, i.e., the corporation tax. Here we are faced with a puzzle. On the one hand, the statutory corporate income tax rate has fallen significantly in almost all OECD countries since the early 1980s, as illustrated in Figure 2. On the other hand, corporate tax revenues relative to GDP have actually increased in most countries, the main exceptions being Germany, Japan, and the UK, as shown in Figure 3. Hence the corporate income tax base must have grown sufficiently to (over)compensate for the drop in the statutory tax rate.

To explore these trends in greater detail, it is useful to decompose the ratio of corporate tax revenue to GDP in the following manner:

$$
\frac{R}{Y}=\frac{R}{C} \cdot \frac{C}{P} \cdot \frac{P}{Y}
$$

\footnotetext{
${ }^{6}$ Gordon (op.cit.) and Razin and Sadka (op.cit.) did not explicitly include rents in their analysis, but their reasoning implies that a source-based tax on perfectly mobile rents is no less distortionary than a source tax on the normal return, as pointed out by Gordon and Hines (2002).
} 
Figure 2: Statutory corporation tax rates

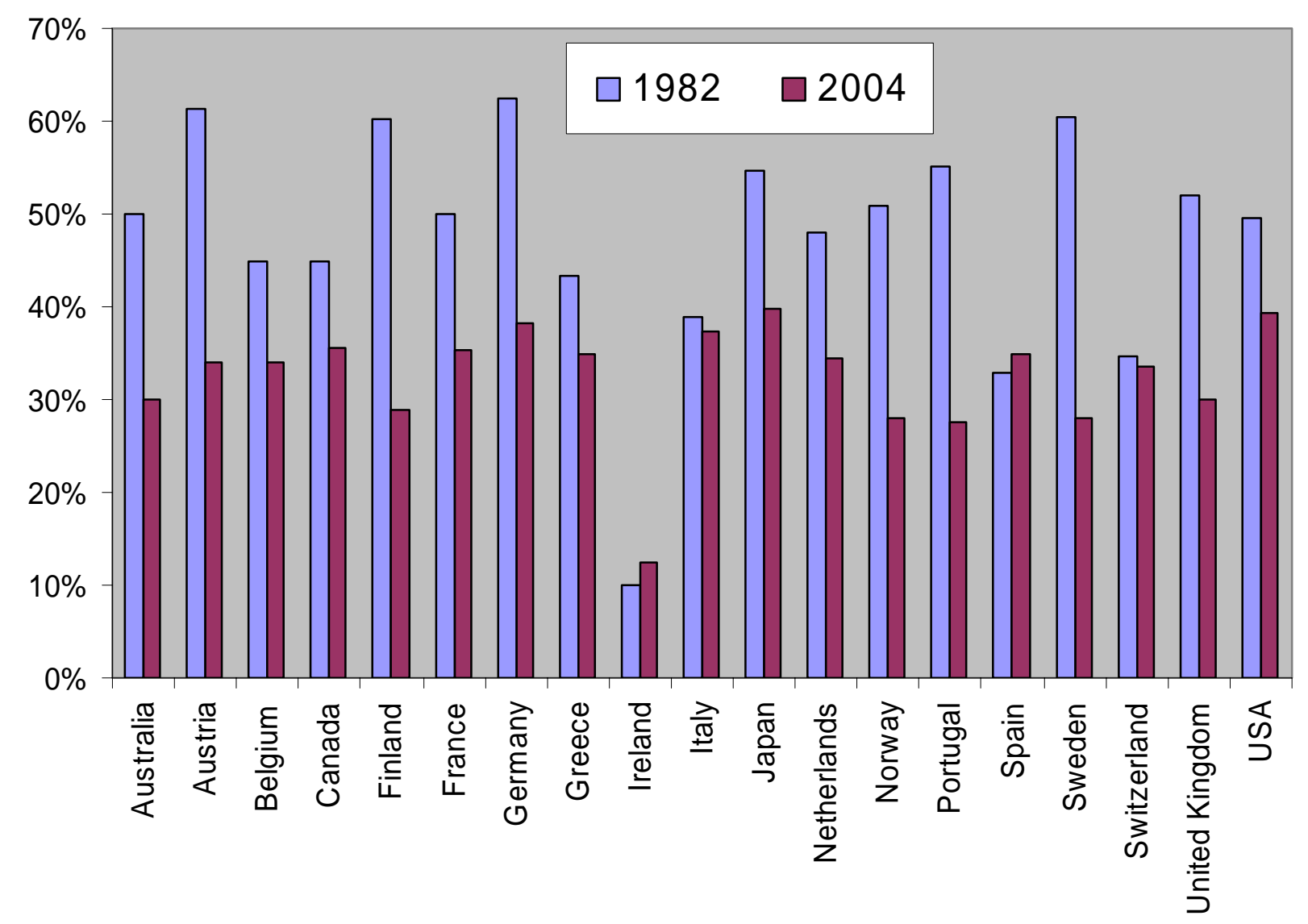

Notes: For countries using different tax rates, the manufacturing rate is chosen. Local taxes (or the average across regions) are included where they exist. Any supplementary taxes are included only if they apply generally, rather than only under particular circumstances. Data for Denmark and Luxembourg are missing. Source: Devereux and Sørensen (2005), based on OECD data.

Here $R$ is total corporate tax revenue, $Y$ is GDP, $C$ is the total profit earned in the corporate sector, and $P$ is the total profit earned in the economy as a whole. The fraction $R / C$ may be seen as a rough indicator of the average effective corporate tax rate, since it measures total corporate taxes paid relative to the total pre-tax earnings of the corporate sector. ${ }^{7}$ Thus the decomposition suggested above will show whether an increase in the ratio of corporate tax revenue to GDP is due to an increase in the effective tax burden on the corporate sector, $R / C$; whether it reflects an increase in the share of total profits accruing to the corporate sector, $C / P$; or whether it is due to an increase in the profit share of total GDP, $P / Y$.

\footnotetext{
${ }^{7}$ Of course this is a very primitive measure of the effective tax rate. Estimating effective tax rates is an academic industry in itself. For an overview and discussion of alternative methods, see Sørensen (ed., 2004).
} 
Figure 3: Corporate tax revenue (\% of GDP)

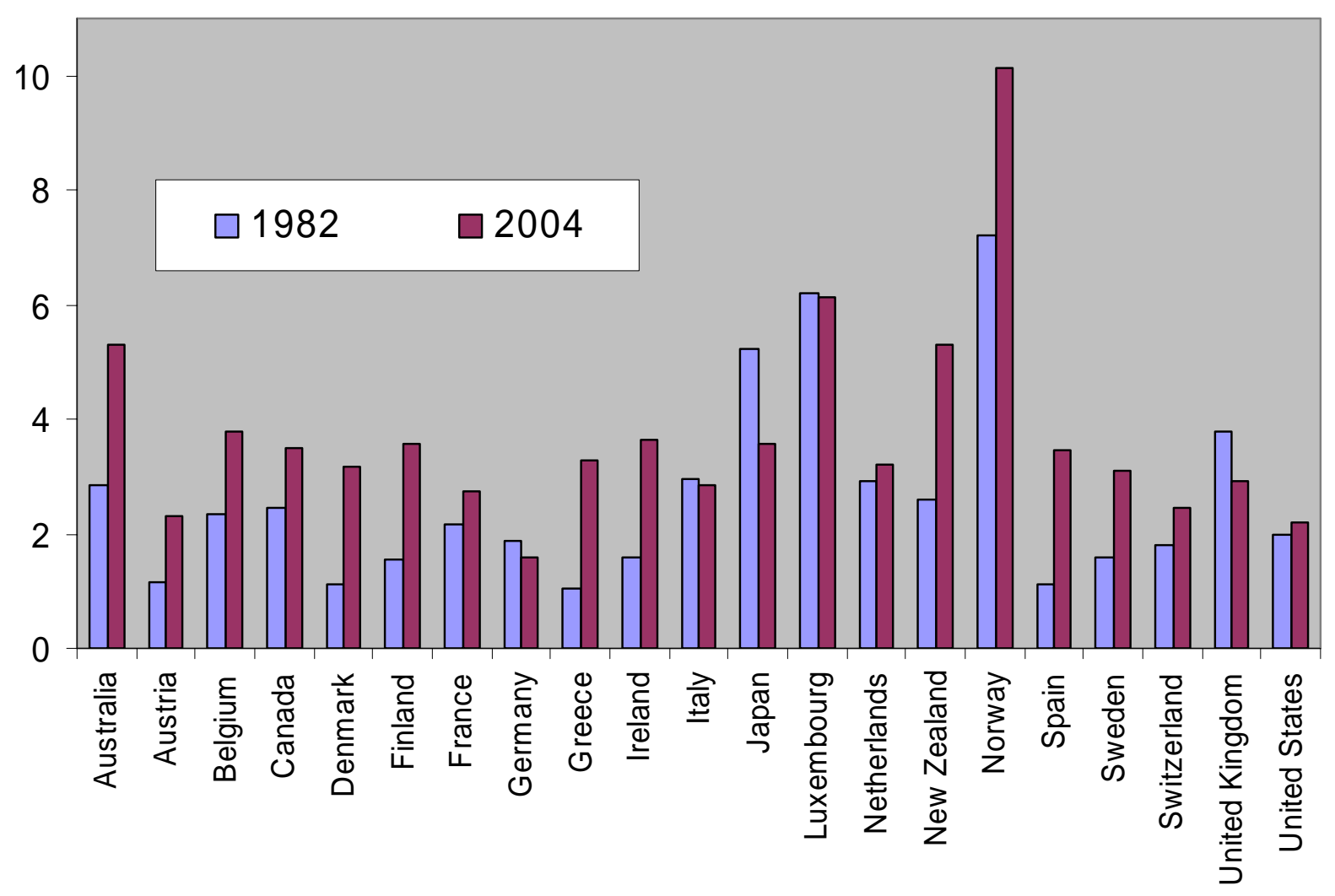

Notes: All taxes levied on profits and capital gains of corporations are included.

Source: Devereux and Sørensen (2005), based on OECD data.

In Figure 4 we have undertaken such a decomposition of the ratio of corporate tax revenue to GDP for a number of OECD countries for which the necessary national income statistics were available back to the early $1980 \mathrm{~s} .{ }^{8}$ Note that the concept of 'profit' adopted here is the OECD measure of 'operating surplus', defined as profit gross of interest and depreciation, i.e., a measure that is broader than the actual business income tax base. This explains why the estimated effective tax rates $(R / C)$ are relatively low compared to the statutory tax rates in Figure 2. To eliminate some of the cyclical fluctuations in the data, Figure 4 shows three-year moving averages centred on the year indicated on the horizontal axis. We see that in most of the countries the ratio of corporate profits to total profits has tended to increase, reflecting the growing importance of the corporate organizational form. Thus part of the reason why governments have managed to stabilize or even

\footnotetext{
${ }^{8}$ We left out Germany because of lack of a time series of sufficient length. We also left out Norway, where corporate tax revenues are heavily influenced by fluctuations in the petroleum sector, and Japan where developments have been strongly affected by the protracted economic crisis of the 1990s.
} 
Figure 4: The ratio of corporate tax revenue to GDP and its components (percent)
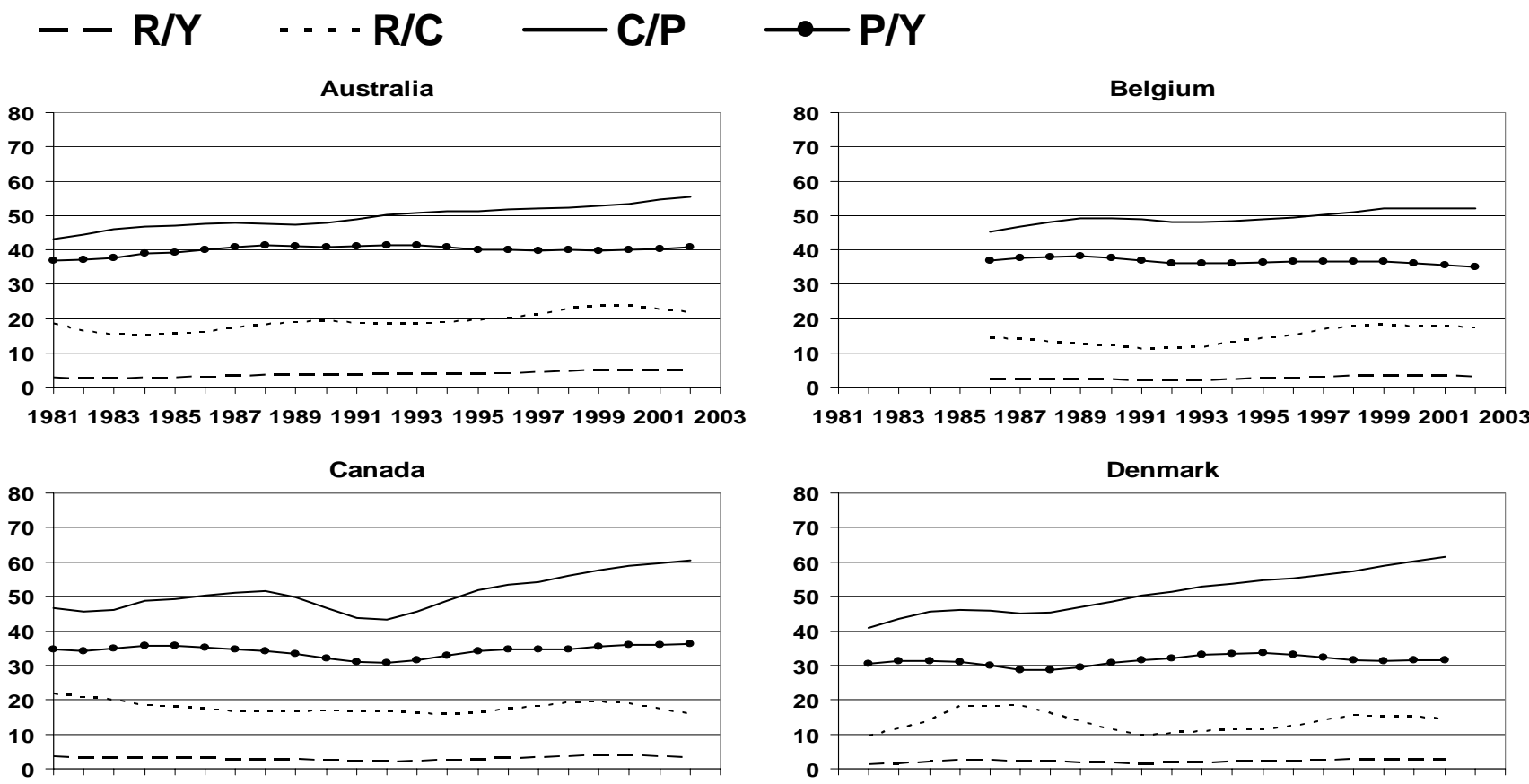

198119831985198719891991199319951997199920012003 198119831985198719891991199319951997199920012003
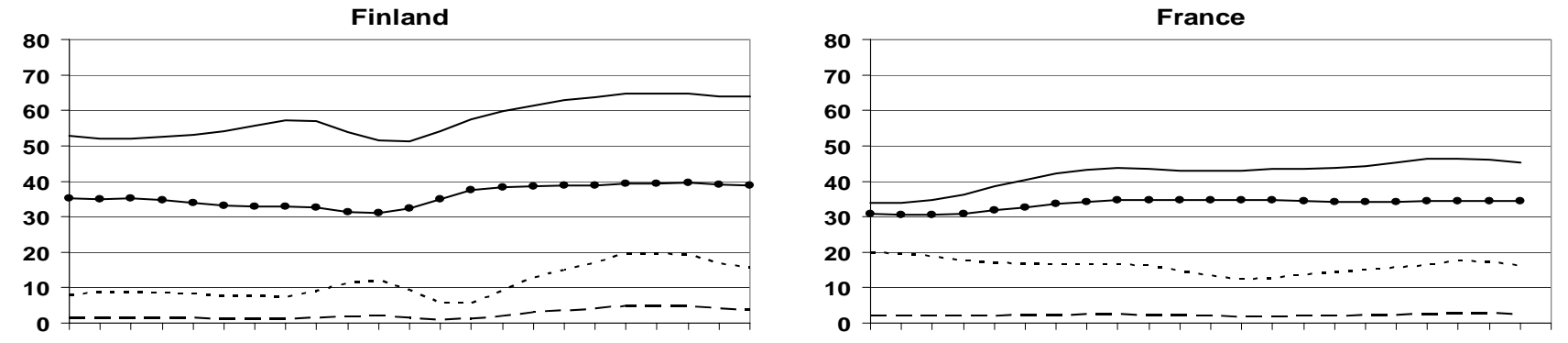

198119831985198719891991199319951997199920012003 Italy
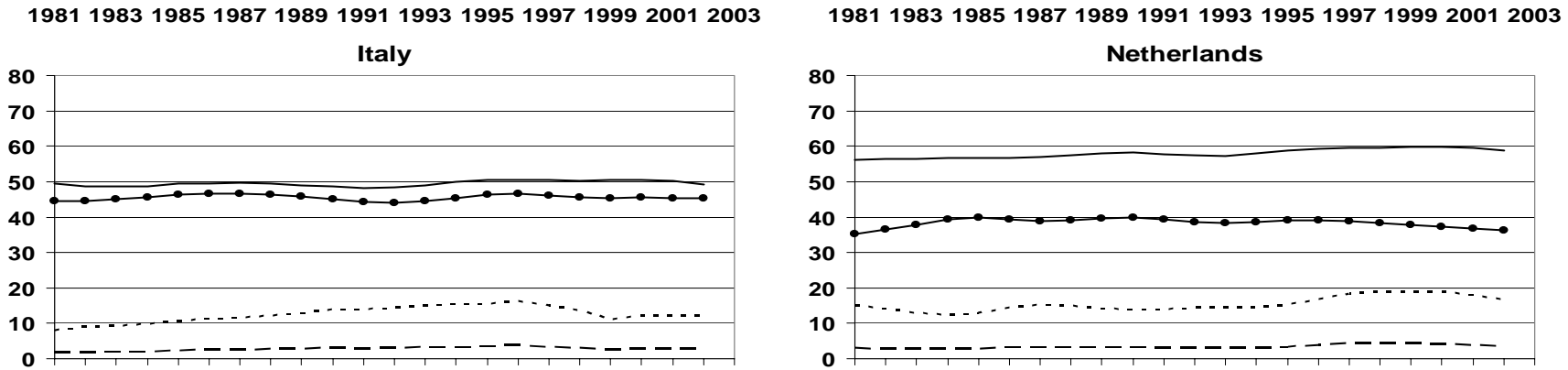

198119831985198719891991199319951997199920012003 United Kingdom
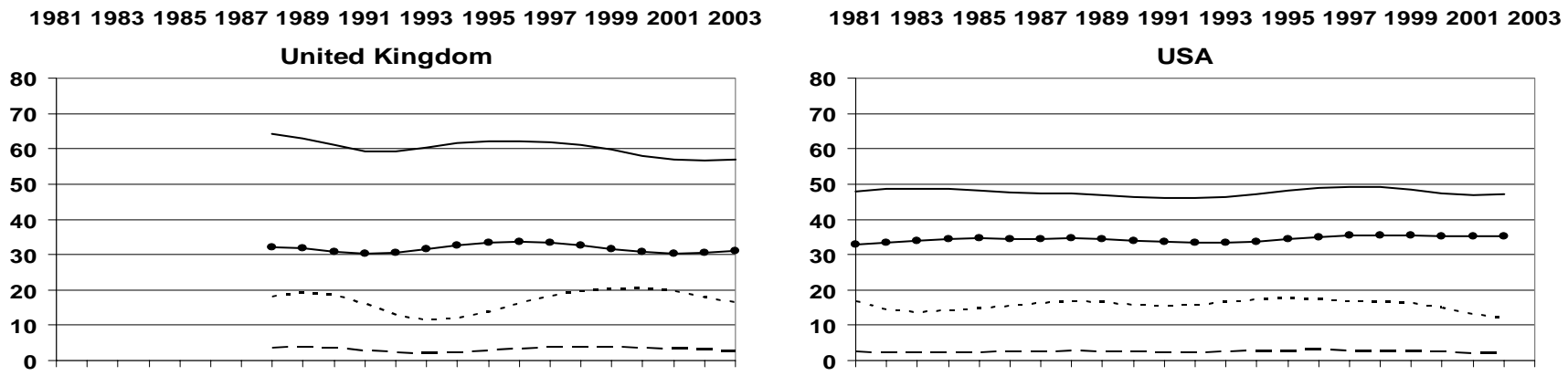

198119831985198719891991199319951997199920012003

198119831985198719891991199319951997199920012003

Source: Own calculations, based on OECD National Accounts. 
increase the ratio of corporate tax revenues to GDP is that the corporate sector has tended to expand at the expense of non-corporate firms. In part this may reflect the secular decline of certain sectors such as agriculture where the non-corporate organizational form has tended to dominate, but it may also reflect income-shifting into the corporate sector induced by the large drops in statutory corporate tax rates. ${ }^{9}$ In both cases the gain in corporate tax revenue will tend to be offset by a loss of revenue from the personal income tax. However, none of the countries shown in Figure 4 have experienced a significant drop in their aggregate effective corporate tax rate $(R / C)$, and in several countries such as Australia, Belgium, Denmark, Finland, and France, the effective corporate tax rate even seems to have increased. In other words, it seems that governments have made up for the drop in statutory tax rates by broadening the corporate tax base, e.g., by eliminating special deductions and moving towards less generous rules for asset depreciation etc., in line with the tax-cut-cumbase-broadening philosophy that became popular in the 1980s and early 1990s.

\subsection{Why do source-based capital income taxes survive?}

\subsubsection{Reasons for the viability of source taxation}

Whereas the basic theory of optimal taxation suggests that globalisation will gradually wipe out source-based capital income taxation, we have seen that corporation tax revenues have actually been very robust in recent decades. This section briefly discusses various reasons why source-based capital income taxes may be able to survive despite growing capital mobility. ${ }^{10}$

Location-specific rents. If firms can earn above-normal returns by investing in a particular location, the government of that jurisdiction may impose some amount of source tax without scaring investors away. There are many potential sources of location-specific rents such as the existence of natural resources, an attractive infrastructure, availability of a pool of qualified labour and, more generally, the existence of 'agglomeration forces' (to be elaborated in section 1.3.2). Moreover, when location-specific rents co-exist with foreign ownership of (part of) the domestic capital stock, the incentive for national governments to levy source-based capital taxes is strengthened, since they can thereby export part of the domestic tax burden to foreigners whose votes do not count in the domestic political process (see Huizinga and Nielsen (1997)). Since globalisation implies increased international cross-hauling of investment and a resulting increase in foreign ownership shares, this may be an important reason why governments choose to maintain source-based capital income taxes, as suggested by Mintz (1994). Indeed, using European data,

\footnotetext{
${ }^{9}$ Fuest and Weichenrieder (2002) offer evidence that such income-shifting is indeed taking place.

${ }^{10}$ For a further discussion of this issue, see Zodrow (2006).
} 
Huizinga and Nicodéme (2003) found evidence of a significant positive relationship between average effective corporate tax rates and the share of domestic companies owned by foreigners. Nevertheless, since a source tax on the normal return can be fully shifted under perfect capital mobility, the factors mentioned above do not explain why governments choose to levy a distortionary source tax on the full return to capital rather than taxing only rents, e.g., by allowing a deduction for the normal return to capital. I return to this issue at the end of this subsection.

Imperfect capital mobility. The prediction that source taxes on capital will vanish assumes that capital is perfectly mobile. In practice, there are costs of adjusting stocks of physical capital so such capital cannot move instantaneously and costlessly across borders. Since adjustment costs tend to rise more than proportionally with the magnitude of the capital stock adjustment, the domestic capital stock will only fall gradually over time in response to the imposition of a sourcebased capital income tax (see Wildasin (2000)). In present value terms, the burden of the tax therefore cannot be fully shifted onto domestic immobile factors, and hence a government concerned about equity may want to impose a source-based capital tax, particularly if it has a short horizon. Another reason for imperfect capital mobility may be that financial instruments (in particular shares) issued in different countries are imperfect substitutes because they have different risk characteristics, as will be the case when returns in different national stock markets are not perfectly correlated. Investors will then want to hold securities issued in different countries to diversify their portfolios, and individual countries will have some market power over the price of equity in domestic firms. Governments may exploit this market power by imposing withholding taxes at source on returns on domestic equity paid out to foreign investors, just as a country with international market power may want to impose an optimal tariff (see Gordon and Varian (1989)). Gordon (2000, p. 31) points out that a roughly similar result may be achieved by imposing a sourcebased corporation tax and granting a personal tax credit for the corporation tax only to domestic shareholders, as many governments have actually done. Governments may also exploit the fact that different types of business activity have different degrees of international mobility by granting selective tax cuts to the most mobile activities. This is the background for the proliferation of the special tax regimes which are the targets of the OECD initiative against 'harmful tax competition' and of the EU Code of Conduct for business taxation. ${ }^{11}$

Foreign tax credits. Some important capital exporting countries like the US, UK and Japan try to tax the worldwide profits of their multinational corporations while allowing a foreign

\footnotetext{
${ }^{11}$ For further discussion of these initiatives, see Eggert and Haufler (2006).
} 
tax credit for taxes paid abroad, up to a limit given by the amount of domestic tax on the foreign source income. In these cases the foreign host (source) countries have an obvious incentive to levy a source-based corporation tax, since they can do so without reducing the incentive of foreign multinationals to invest in the domestic economy, as long as the domestic corporation tax does not exceed the corporation tax levied by the home (residence) country of the multinational company. It is less clear why the home country government would want to offer a foreign tax credit which effectively amounts to a give-away of revenue to foreign host governments. Gordon (1992) argues that foreign tax credits are offered exactly because they give an incentive for foreign host countries to levy source-based taxes up to the limit given by the domestic tax rate. In this way the foreign tax credit enables the home country to tax domestic investment without inducing a capital flight from the domestic economy. However, as recognized by Gordon himself (Gordon (2000), pp. 27-28), this argument rests inter alia on the counterfactual assumption that home countries tax foreign source income upon accrual. In practice, home country tax is typically levied only when income is repatriated from abroad. As long as profits are retained and reinvested abroad, only the host country tax rate matters for the cost of capital, as Hartman (1985) showed, and taxation at the margin is then effectively source-based. Moreover, a large number of countries explicitly adhere to the source principle by exempting foreign source corporate income from domestic corporation tax. Overall, Gordon and Hines (2002) find it difficult to argue that crediting arrangements have a significant impact on host country corporate tax rates.

The corporation tax as a backstop to the personal income tax. One important function of the corporate income tax is to serve as a 'backstop' for the personal income tax. The corporation tax falls not only on returns to (equity) capital but also on the labour income generated by entrepreneurs working in their own company. In the absence of a corporation tax, taxpayers could shift labour income and capital income into the corporate sector and accumulate it free of tax while financing consumption by loans from their companies. Still, while it is easy to see why protection of the domestic personal tax base may require a corporation tax on companies owned by domestic residents, it is not obvious why it requires a source-based corporation tax on foreign-owned companies whose shareholders are not liable to domestic personal tax. However, as pointed out by Zodrow (2006, p. 272), if foreign-owned companies were exempt from domestic corporate income tax, it might be relatively easy to establish corporations that are nominally foreign-owned but are really controlled by domestic taxpayers, say, via a foreign tax haven. Hence the backstop function of the corporation tax may be eroded if it is not levied on foreign-owned companies. 
Political constraints. Finally, even though it may be inefficient to tax capital income at source, the voting public may not realize that such a tax tends to be shifted to the immobile factors, so levying a source-based corporation tax may be a political necessity, since abolition of such a tax would be seen as a give-away to the rich, including rich foreign investors. More generally, if there are political limits to the amount of (explicit) taxes that can be levied on other bases, it may be necessary for a government with a high revenue requirement to raise some amount of revenue via a source-based capital income tax, even if such a tax is highly distortionary. Governments could then try to restructure the corporation tax to reduce the inevitable distortions. For example, by broadening the corporate tax base and lowering the statutory rate, a country may be able to raise a given amount of corporate tax revenue in a more efficient manner. One reason is that a lower statutory tax rate makes a country less vulnerable to international profit-shifting through transfer-pricing and thin capitalization etc., as emphasized by Haufler and Schjelderup (2000). Another reason may be that a low statutory tax rate is particularly beneficial for highly profitable companies which are often multinationals earning firm-specific mobile rents from the exploitation of special technologies, brand names etc. Keeping the statutory tax rate low may thus be a way of attracting the type of high-tech investment that gives rise to positive spillovers to the domestic economy. In summary, a perceived political need to raise a certain amount of revenue from the corporation tax combined with the incentives to lower the statutory tax rate in a globalising economy may help to explain the policy of tax-cut-cum-base-broadening pursued by most OECD governments in recent decades. ${ }^{12}$

\subsubsection{Agglomeration, trade costs and the future of capital income taxes}

As noted above, location-specific rents are one important reason why source-based capital taxes may be sustained. The modern theory of economic geography (e.g., Baldwin et al., (2003), Baldwin and Krugman (2002) and Kind et al. (2000)) highlights how such rents are created and destroyed. It also suggests that the link between economic integration and taxation is more complex than previously thought. This theory seeks to explain the geographical pattern of economic activity by accounting for transportation costs as well as other barriers to international trade. Specifically, the theory identifies factors which tend to disperse economic activities across the geographical space as well as factors working in favour of a geographical concentration (agglomeration) of activities. When firms deliver inputs to each other and there are costs of long-

\footnotetext{
${ }^{12}$ Undoubtedly, this policy was also partly motivated by a desire to reduce domestic distortions to resource allocation by creating a more level playing field for domestic investment.
} 
distance trade in inputs, they can save on transportation costs by locating near each other. Thus forward-linkages (input deliveries) among firms create an incentive for agglomeration. This incentive increases if agglomeration also stimulates technological spillovers among firms, for example, by making it easier for them to observe and learn from each others' production processes.

On the other hand, firms also compete with each other in final product markets, so if product markets are to some extent geographically segmented due to transport costs, increased concentration of activity in one location will tend to intensify competition and drive down profit margins in that local market. This crowding effect creates an incentive for firms to operate in different locations to reduce the intensity of competition. However, if the crowding effect is not too strong, firms will tend to agglomerate (concentrate) in certain geographical areas. As a result of the cost savings arising from agglomeration, firms will earn location-specific rents in these areas, and these rents can be taxed away via the corporation tax without inducing firms to relocate to other jurisdictions.

Economic integration is driven by lower trade costs which reduces the individual firm's cost advantage of being close to the suppliers of its intermediate inputs. Clearly this tends to reduce the location-specific rents from agglomeration, thereby reducing the scope for source-based taxation. At the same time lower trade costs increases the scope for price competition via longdistance trade in final products. This will reduce the crowding effect from agglomeration, since the degree of competition becomes less dependent on the geographical closeness of the individual firm's competitors. Obviously a smaller crowding effect tends to increase the location-specific rent from agglomeration. It is quite possible that this latter effect of lower trade costs may be stronger than the former one, in which case lower trade costs will induce governments in countries with many agglomerations to increase their tax rates.

In fact models of economic geography typically imply a non-monotonic relationship between trade costs and the rents from agglomeration: starting from relatively high trade costs, a fall in these costs will at first tend to increase the location-specific rents from agglomeration, but when trade costs fall below a certain level, a further fall will reduce the agglomeration rents, as illustrated in Figure 5. The intuition is straightforward: with very high trade costs, there is no scope for trade in intermediate and final goods, so local markets can only be served by local firms, leaving no room for a geographical concentration of production and the associated agglomeration rents. At the other end of the spectrum, if trade costs are zero the price of inputs and the degree of competition in product markets becomes quite independent of the geographical location of 
production, so again there are no agglomeration forces. It follows that if there is any potential for agglomeration rents at all, these rents must initially rise from zero to some positive level as trade costs start to come down from a very high level, but at some point if trade costs continue to fall, agglomeration rents must start to decline again.

This suggests that, in the early stages of economic integration, a move towards more integration may well increase the scope for taxation of mobile factors for a while. But as integration deepens and trade costs lose importance, the location-specific rents that enable governments to levy source taxes without deterring inward investment tend to get wiped out. Thus, if the recent wave of globalisation has so far involved a leftward move from a starting point to the right of the maximum of the curve in Figure 5, rising agglomeration rents may help to explain the observed robustness of corporate tax revenues, but according to the theory of economic geography this is no guarantee that source-based capital taxes can be maintained in the future if trade costs continue to fall. Although those who fear a race to the bottom in capital income taxes may seem to have cried 'wolf' too many times, the wolf may yet show up some day!

\section{Figure 5. The relationship between trade costs and the rents from agglomeration}

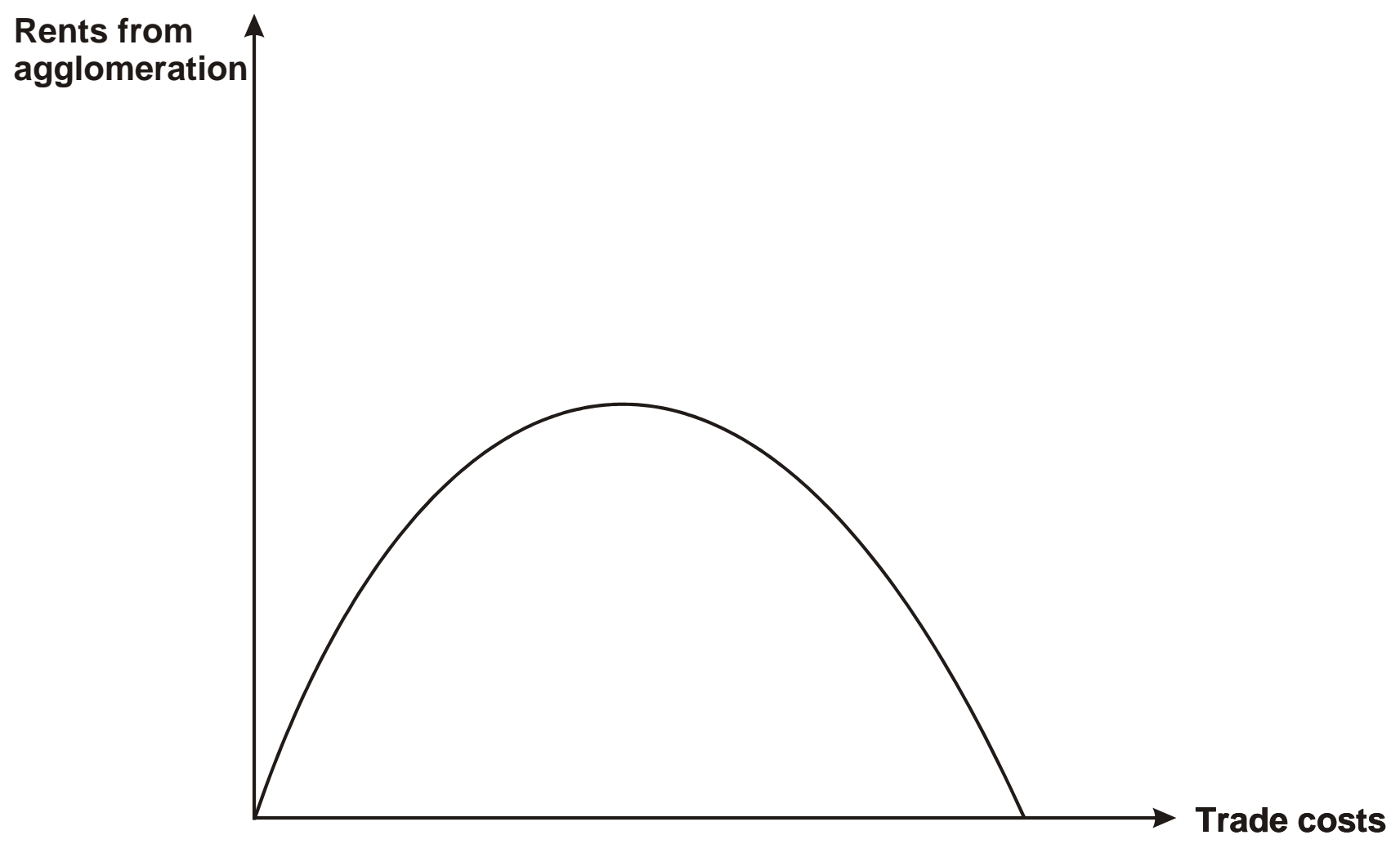




\subsection{Should the normal return to capital be taxed?}

From a theoretical viewpoint, there is an obvious case for a tax on rents, since such a tax is in principle non-distortionary, at least if the rents are location-specific. A long-standing debate in the theory of taxation is whether governments should also tax the normal return to capital. This section reviews the main arguments in this perennial debate. ${ }^{13}$

As we have seen, a source-based tax on the normal return tends to be shifted onto the immobile domestic factors, so in the open economy a genuine tax on the normal return to saving must be residence-based, falling on income from foreign as well as domestic sources. The next section discusses whether the residence principle can actually be implemented, but in order to distinguish normative theoretical arguments from administrative concerns, the present section assumes that a residence-based capital income tax can indeed be enforced.

A tax on the normal return to saving increases the relative price of future consumption by raising the amount of present consumption that has to be given up to allow a unit increase in future consumption. Hence a capital income tax (on the normal return) may be seen as a selective commodity tax on future consumption. As argued by Chamley (1986) and Judd (1985), in the long run such a tax seems very hard to defend in an economy where consumers behave as if they have an infinite time horizon, say, because generations are linked through altruistic bequests in the manner described by Barro (1974). To see why, note that from the standpoint of period zero, the relative price of consumption in some future period $T$ (i.e., the amount by which consumption in period 0 must be cut in order to increase consumption in period $\mathrm{T}$ by one unit) is

$$
P_{T}=\prod_{t=0}^{T} \frac{1}{1+r_{t}\left(1-\tau_{t}\right)}=\prod_{t=0}^{T}\left(\frac{1}{1+r_{t}}\right)\left(\frac{1+r_{t}}{1+r_{t}\left(1-\tau_{t}\right)}\right)
$$

where $r_{t}$ is the pre-tax rate of return on saving in period $t$ and $\tau_{\mathrm{t}}$ is the capital income tax rate for that period. The last bracket in this expression measures the tax-induced distortion to the relative price of future consumption. This distortion to $P_{T}$ will be larger the longer the consumer's time horizon $T$, and as the horizon tends to infinity, the tax distortion becomes infinitely large. Clearly it is hard to think of circumstances in which it would be optimal to impose an infinitely large tax distortion, and Chamley (1986) and Judd (1985) do indeed find that in the long run the capital income tax rate should be lowered to zero even if the alternative pubic revenue sources are also

\footnotetext{
${ }^{13}$ Parts of this section draw on Sørensen (2005b). Bernheim (2002) and Auerbach (2006) also review some of the main arguments in the debate on the optimal taxation of capital income.
} 
distortionary, and even if the government is concerned about equity as well as efficiency. ${ }^{14}$ To be sure, in the short and medium run where the relative price distortion caused by capital income taxation is finite, it is typically optimal to levy a positive capital income tax, but in a standard Ramsey type infinite-horizon model the tax rate should gradually be lowered as the size of the distortion increases.

This policy conclusion assumes that capital markets are perfect so that consumers may freely reallocate their consumption over time through borrowing and lending. If intertemporal substitution in consumption is restricted by borrowing constraints, consumers can respond only to a limited extent to the relative price distortions caused by capital income taxation. When labor income is uncertain and insurance markets are incomplete, it may then be optimal to levy a capital income tax even if consumers have infinite horizons (see Aiyagari (1993) and Chamley (2001)). With constraints on borrowing, consumers will engage in precautionary saving to hedge against future rainy days, and consumption at any given date will tend to be positively correlated with accumulated precautionary saving. A tax on (income from) capital that finances a lump-sum transfer will then help to redistribute income from high consumption states to low consumption states, thereby performing an insurance function that the market cannot provide. ${ }^{15}$

A limitation of infinite-horizon models is that many consumers may not behave as if they live forever. For example, they may not have any heirs or may not care sufficiently about them to leave them any positive bequests, or their bequest motive may be selfish rather than altruistic. Many scholars have therefore studied optimal capital income taxation in models with finite consumer horizons such as the Diamond life cycle overlapping-generations model. In such models several rationales for a positive capital income tax rate have been identified, including the following:

Complementarity between leisure and future consumption. As pointed out long ago by Corlett and Hague (1953), a commodity tax system which minimizes deadweight loss will impose heavier taxes on goods that are more complementary to (less substitutable for) leisure should carry a relatively high tax rate, since this will minimize tax-induced substitution towards leisure. Because a capital income tax is a tax on future consumption, the Corlett-Hague rule implies

\footnotetext{
${ }^{14}$ Another way of explaining this result is to note that, in the Ramsey infinite horizon model, the after-tax steady-state interest rate is closely tied to the consumer's exogenous utility discount rate, so a capital income tax gets fully shifted onto the pre-tax interest rate. Effectively this means that savings are infinitely elastic in the long run, and clearly it is inoptimal to tax a factor in infinitely elastic supply.

${ }^{15}$ Allowing for an arbitrary length of consumer horizons (finite or infinite), Golosov et al. (2003) also find that the optimal capital income tax rate is positive when labour income is stochastic, even in circumstances where a zero capital income tax rate would be optimal under perfect foresight.
} 
that we should tax (subsidize) capital income if future consumption is more (less) complementary to leisure than present consumption. In the benchmark case where preferences are separable in consumption and leisure so that current and future consumption are equally substitutable for leisure, we have the powerful theorem of Atkinson and Stiglitz (1976) that a government concerned about equity as well as efficiency will not want to differentiate taxes across commodities (and hence should not impose a capital income tax), provided it can use a progressive non-linear labour income tax to achieve its distributional goals. The intuition for the Atkinson-Stiglitz result is clear: there is no second-best efficiency case for distorting the choice between present and future consumption when these goods are equally substitutable for leisure; nor is there any equity case for imposing a tax on future consumption, since a wage income tax is a better targeted instrument for redistributing income in a world where innate differences in labour productivity is (assumed to be) the only source of inequality. A widespread view among public finance economists is that we do not know whether future consumption is more or less substitutable for leisure than present consumption, so based on the principle of insufficient reason, we should assume equal degrees of substitutability. The Atkinson-Stiglitz theorem then immediately leads to the prescription of a zero tax rate on the normal return to capital. This view has recently been challenged by Erosa and Gervais (2002). They show that for any reasonable parameterization, a standard life cycle overlapping-generations model implies that consumption and leisure generally move together over time at the level of the individual consumer. In other words, if life cycle models provide a reasonable approximation to reality, it is reasonable to assume that future consumption is more complementary to leisure than present consumption, and hence it is efficient to tax future consumption via a capital income tax. The simulations undertaken by Erosa and Gervais (op.cit.) indicate that the optimal capital income tax rate is indeed significantly above zero for any plausible parameterization of the life cycle OLG model.

Mimicking age-dependent labour income taxation. Erosa and Gervais (2002) also point out that the elasticity of labour supply with respect to the relative price of leisure tends to increase with age in a realistic life cycle model. Ideally, the government would therefore want to impose an age-dependent labour income tax, with a marginal tax rate that declines with age. If the labour income tax cannot be conditioned on age, the government can (imperfectly) imitate an agedependent labour tax by levying a positive capital income tax. To see this, note that if the marginal after-tax wage rate in some future period $T$ is $W_{T}$, the relative price of leisure in that period (as seen from the present when the consumer plans the time profile of his labour supply) is $P_{T} W_{T}$, where $P_{T}$ 
is given by equation (2) above. By imposing a capital income tax $\tau_{\mathrm{t}}$ the government can thus raise the relative price of leisure in later stages of the consumer's life cycle where labour supply tends to be more elastic.

Capital-skill complementarity and endogenous factor prices. The analysis of Atkinson and Stiglitz (1976) was static and did not allow for the fact that saving for future consumption induces capital accumulation which in turn affects pre-tax factor incomes. However, subsequent research has shown that, provided the government has other instruments (such as debt policy or public investment) to steer the capital stock towards its socially optimal level, a zero steady-state capital income tax rate remains optimal in explicitly dynamic OLG models with capital accumulation, as long as utility functions are weakly separable in consumption and leisure (see Ordover and Phelps (1979)). But the reason why dynamic models of capital accumulation confirm the optimality of a zero capital income tax is that capital accumulation does not affect the distribution of pre-tax wage rates in these models: a higher capital stock simply raises the level of real wages in the same proportion across all skill types. Yet there is strong empirical evidence that skilled labour is more complementary to capital than unskilled labour (see, e.g., Krusell et al., (2000) and Lindquist (2005)), implying that capital accumulation will tend to raise the relative wages of skilled workers. In that case capital accumulation means that a skilled worker has to work fewer hours to earn the same income as an unskilled worker. Ceteris paribus, this makes it more attractive for a skilled worker to mimic an unskilled worker, so the non-mimicking constraint that limits the government's ability to redistribute income from the high-skilled to the low-skilled becomes tighter. To offset this, it becomes optimal for a government concerned about equity to dampen saving and capital accumulation through a positive capital income tax, as shown by Salanié (2003, p. 143).

Offsetting the labour tax distortion to human capital investment. Bovenberg and Jacobs (2005a) have pointed to another rationale for a positive capital income tax: when human capital investment is endogenous and its opportunity cost is not fully tax deductible (say, because part of the opportunity cost is a non-pecuniary cost of effort), a labour income tax will discourage human capital formation and induce consumers to substitute financial capital for human capital. If the government can fully observe all human capital investments and their related opportunity costs, education subsidies are the most well-targeted instrument to offset the labour tax distortion to human capital investment, as Bovenberg and Jacobs (2005b) have shown in a companion paper. However, realistically governments cannot verify all human capital investments and their associated 
costs. In that case it becomes second-best optimal to supplement education subsidies by a positive capital income tax to offset the tendency of the labour income tax to favour financial investment over human capital investment. The more the government wishes to redistribute income through a progressive labour income tax, higher is the optimal capital income tax rate needed to offset distortions to human capital investment.

In summary, recent research has shown that a case for a positive capital income tax rate can be made both on efficiency and equity grounds.

\subsection{Can taxes on saving be enforced?}

While there may be a normative case for a positive residence-based tax on the normal return to saving, tax economists tend to argue that the residence principle cannot be enforced in practice, since governments cannot effectively monitor foreign source income in the absence of systematic international exchange of information among tax authorities. To be sure, bilateral tax treaties do provide for exchange of information on specific taxpayers upon request from the residence country, and sometimes treaties also encourage 'spontaneous' provision of specific information by the source country, but is is widely agreed that information exchange on such limited scale is insufficient to bring all foreign source capital income into the tax net of residence countries. According to the pessimistic but widespread view expressed by Tanzi and Zee (2001), the basic problem is that source countries seem to have no interest in providing information since they thereby make themselves less attractive as a haven for foreign investors.

However, some authors have recently tried to identify circumstances in which it would indeed be in the mutual interest of source and residence countries to engage in systematic international information exchange (see, e.g., Bacchetta and Espinosa (2000), Eggert and Kolmar (2002), Huizinga and Nielsen (2003), and Keen and Ligthart (2006)). In particular, Keen and Ligthart (op.cit.) show that if the residence country is willing to transfer an appropriate share of its revenue gain from information exchange to the source country, both countries will benefit from systematic information exchange.

Moreover, recent years have seen significant progress in international cooperation on information exchange. As part of the OECD initiative to counter 'harmful tax practices', 30 out of 35 jurisdictions originally identified as international tax havens have now committed themselves to providing information to foreign tax authorities, and under the recent EU agreement on the socalled savings directive, 22 out of $25 \mathrm{EU}$ member states have implemented automatic information exchange from July 2005. The remaining three member countries will adopt information exchange 
from 2011, relying on withholding taxes until then. To make the switch to information exchange more attractive to these member states, the EU savings directive contains an innovative clause requiring them to transfer 75 percent of the revenue from withholding taxes to the residence country.

Still, it must be acknowledged that as long as some jurisdictions refuse to cooperate on information exchange, wealthy investors may be able to escape residence country tax by hiding away their wealth in foreign accounts. Yet governments may be able to collect some revenue from taxes on saving due to the well-documented 'home bias' in investor portfolios, i.e., the fact that financial investors (especially small ones) tend to invest the bulk of their wealth at home rather than abroad (see, e.g., French and Poterba (1993)). In part this home bias may reflect that (small) investors are less well informed about foreign than about domestic investment opportunities (see Gordon and Bovenberg (1996) and Westerhout (2002)). It may also reflect that returns on domestic equity tend to be negatively correlated with domestic wage rates, giving domestic workers a hedging motive to invest in domestic rather than foreign shares, as argued by Bottazzi et al. (1996). Whatever its source may be, the persistence of home bias clearly enables governments to levy some amount of tax on the savings of domestic residents without inducing a capital flight, even though it is less clear that a positive capital income tax rate is indeed optimal when only domestic-source income can be taxed (see Gordon (2000) for a further discussion of this point).

This last observation takes us back to the question of the administrative feasibility of residence-based taxation. Although (small) domestic household investors tend to have zero or only small direct holdings of foreign assets in their portfolios, a large part of household saving is channelled through institutional investors such as mutual funds, pension funds and life insurance companies that may hold significant amounts of foreign assets. Because of their limited number and public reporting requirements, the foreign source income of such institutional investors is much easier to monitor than the foreign income of individual households. Given the strong revealed household preference for channelling saving through these financial intermediaries, it should be technically possible to enforce residence-based taxation of the return to most of private sector saving by collecting the tax at the level of the institutional investors. In fact, Denmark and Sweden do tax the return to retirement savings undertaken via banks, pension funds and life insurance companies. ${ }^{16}$ Still, the international norm is to exempt the return to retirement saving from tax, but

\footnotetext{
${ }^{16}$ The tax rate is rather modest, however, amounting to 15 percent in both countries. While the Danish tax is levied on the actual accrued return on the assets of the institutional investor, the Swedish tax is levied on an imputed return equal to the average interest rate on government bonds.
} 
this suggests that the failures of governments in implementing the residence principle stem to a large extent from a deliberate political choice to exempt a big chunk of capital income from tax.

\subsection{Do we actually collect any revenue from taxing normal returns?}

Indeed, there are several indications that governments do not really want to tax the most important forms of capital income. In most OECD countries the three main forms of private saving are i) savings for retirement; ii) saving in home equity, and iii) retained corporate profits. As already noted, the return to retirement savings is typically tax exempt. The return to owner-occupied housing is the value of the housing service, but hardly any country attempts to levy a tax on imputed rents at a realistic rate, and many countries do not tax imputed rents at all. Finally, while retained corporate profits do bear corporation tax, the corporate income tax rate is often much lower than the top marginal personal income tax rate, and capital gains on corporate shares are often tax exempt or taxed at concessionary rates.

Against this background, it is not surprising that several studies have found that current tax systems collect practically no revenue from taxes on the normal return to capital. For example, Gordon and Slemrod (1988) estimated that in 1983 tax revenue in the United States would have slightly increased in present value terms if the US had eliminated all personal taxes on capital income and all deductions for interest expenses and had allowed expensing rather than depreciation of investment spending on physical capital (thus effectively switching to a cash flow business tax which is known to fall only on pure rents). For 1995, Gordon, Kalambokidis and Slemrod (2001) estimated a slightly positive net revenue from the corporation tax on the normal return, but the revenue only amounted to 4 percent of total corporate profits. Sørensen (1988) found that personal capital income taxes in Denmark generated significant net revenue losses in the mid-1980s, and Becker and Fuest (2005) recently estimated that a switch to a consumption tax in Germany - which would amount to exemption for the normal return to saving - would at most cause a revenue loss of 1.6 percent of GDP and might even yield a net revenue gain.

The fact that so little revenue is raised from taxes on normal returns does not mean that existing capital income taxes are roughly non-distortionary. On the contrary, since the capital income tax base is not adjusted for inflation, the marginal effective tax rate on some forms of saving and investment may be quite high, whereas other forms of saving and investment may receive big tax subsidies. For example, if all of the nominal interest income is subject to full personal tax, the effective tax rate on the real interest income may be quite stiff even at modest rates of inflation. On 
the other hand, in countries that allow deduction for mortgage interest payments without taxing imputed rents, investment in owner-occupied housing will tend to be heavily subsidized by the tax system. Thus, even though on average the tax wedge between the marginal pre-tax return on investment and the marginal after-tax return to saving may be quite low, current systems of capital income taxation probably imply large distortions to the pattern of saving and investment. These observations explain why so many tax economists tend to favour some form of consumption-based taxation which would leave the normal return to capital free of tax. If so little revenue is raised at the cost of such big distortions, why don't we simply give up the idea of taxing the normal return?

In the next part of this paper I will discuss how the tax system of an open economy could be redesigned if governments only wish to tax rents, but I will also discuss how policy makers could reform the system of capital income taxation if they want to make a serious attempt at taxing normal returns.

\section{PART 2. CAPITAL INCOME TAX REFORM IN THE OPEN ECONOMY}

\subsection{A classification of alternative blueprints for capital income tax reform}

In most OECD countries the corporate income tax is a cornerstone of the system of capital income taxation. The corporation tax typically raises a lot more revenue than any other form of capital income tax, and its importance is even bigger than suggested by the revenue statistics because it serves as a backstop to the personal income tax, as mentioned earlier. Hence most of the discussion below will focus on the corporate income tax, although section 2.3 will also consider the role of other capital income taxes.

Since interest payments are deductible from the corporate tax base and are often lightly taxed in the hands of the recipient, say, because they accrue to tax exempt institutional investors, the system of capital income taxation tends to favour debt finance over equity finance. Further, dividends are often taxed at a higher effective rate than the capital gains on shares arising from retained corporate profits, so the tax system also tends to favour equity finance through retained earnings rather than finance via new equity. Apart from distorting financing decisions, the corporate tax system may distort real investment decisions through depreciation schemes that allow depreciation for tax purposes to deviate from the true economic depreciation. Finally, the corporation tax may distort the choice between corporate and non-corporate forms of business organization. 
Over the years, many capital income tax reforms in OECD countries have been motivated by a desire to reduce these well-known distortions. In recent years policy makers have also paid increasing attention to reform proposals intended to make the corporate tax system more robust in a world of growing mobility of capital and of taxable profits. Against this background, Table 1 offers a classification of alternative ways of taxing corporate source income in an open economy. ${ }^{17}$ The rows in the table categorize the different tax systems according to the location of the tax base. Specifically, the tax base may be the corporate income earned in the source country where production takes place; it may be the income earned in the residence country of the company's corporate or personal shareholders, or it may be the sales (net of costs) to the destination country where the final consumption of the company's products occurs. The choice between these alternative tax bases may have important implications for the allocation of capital and economic activity between the domestic and the foreign economy.

The columns in Table 1 classify the different capital income tax systems according to the type of income subject to tax. Traditionally, the corporation tax has been levied on the full return to corporate equity income which includes the normal return as well as pure rents. Alternatively, the corporation tax might be levied on the full return to all capital invested in the corporate sector, including debt capital. Finally, a number of reform proposals would impose corporation tax only on rents, leaving the normal return free of tax. Alternative policy choices in this dimension will affect the degree to which the corporation tax distorts the investment, financing and production activities of companies, and they may also affect international location decisions.

Existing corporate income taxes typically belong to categories 1 or 2 in Table 1 . Under these tax regimes the source country has the prime right to levy tax on corporate profits after deduction for interest payments. The residence country of a multinational parent company may then either exempt the income from foreign corporate affiliates from domestic tax (category 1), or it may subject foreign source profits to domestic corporate income tax but grant a credit for the source country tax against the domestic tax bill (category 2). Under the credit system the domestic tax on 'active' business income is typically deferred until the time of repatriation of foreign source income. For this reason, and because the foreign tax credit typically cannot exceed the amount of domestic tax on the foreign income, the effects on investment incentives of such 'worldwide'

\footnotetext{
${ }^{17}$ To limit the scope of this paper, I have deliberately left several empty cells in Table 1 and have chosen to focus only on those reform options that have been most widely discussed in the international tax policy debate.
} 
Table 1. Alternative systems of capital income taxation

\begin{tabular}{|c|c|c|c|}
\hline \multirow{2}{*}{$\begin{array}{l}\text { Location of } \\
\text { tax base }\end{array}$} & \multicolumn{3}{|c|}{ Type of income subject to business tax } \\
\hline & Full return to equity & Full return to capital & Rent \\
\hline Source country & $\begin{array}{l}\text { 1. Conventional } \\
\text { corporate income tax } \\
\text { with exemption of } \\
\text { foreign source income }\end{array}$ & $\begin{array}{l}\text { 4. Dual Income Tax; } \\
\text { 5. Comprehensive } \\
\text { Business Income Tax }\end{array}$ & $\begin{array}{l}\text { 6. Corporation tax with } \\
\text { an Allowance for } \\
\text { Corporate Equity; } \\
\text { 7. Source-based cash } \\
\text { flow corporation tax }\end{array}$ \\
\hline $\begin{array}{l}\text { Residence country of } \\
\text { corporate head office }\end{array}$ & $\begin{array}{l}\text { 2. Residence-based } \\
\text { corporate income tax } \\
\text { with a credit for foreign } \\
\text { taxes }\end{array}$ & & \\
\hline $\begin{array}{l}\text { Residence country of } \\
\text { personal shareholders }\end{array}$ & $\begin{array}{l}\text { 3. Residence-based } \\
\text { shareholder tax }\end{array}$ & & \\
\hline $\begin{array}{l}\text { Destination country of } \\
\text { final consumption }\end{array}$ & & & $\begin{array}{l}\text { 8. VAT-type } \\
\text { destination-based cash } \\
\text { flow tax }\end{array}$ \\
\hline
\end{tabular}

taxation are rather similar to the effects of the pure source-based system in category $1 .{ }^{18}$ Some countries integrate the corporate and the personal income tax by offering a credit for (part of) the corporation tax against the personal taxes levied on shareholders. However, these countries typically do not extend such tax credits to foreign owners of shares in domestic companies.

As a first approximation, it is therefore fair to say that existing corporate income taxes are source-based, as we have noted previously. Given the high mobility of capital and the opportunities for international profit-shifting through transfer-pricing, royalty payments and thin

\footnotetext{
${ }^{18}$ When the limitation on the foreign tax credit is binding, the net tax paid on the foreign income is equal to the foreign tax rate and the tax collected by the residence country of the parent company is zero, as would be the case under a pure source-based tax system.
} 
capitalization, a source-based tax system is vulnerable to tax competition from foreign jurisdictions. This may be termed "the capital flight problem". All the reform proposals included in Table 1 can be seen as an attempt to reduce this problem in one way or another (as well as an attempt to create greater tax neutrality in the domestic sphere). Thus, a residence-based tax seeks to avoid the problem of capital flight by imposing the same effective tax rate on residents' investment at home and abroad and by exempting inward foreign investment from domestic tax. A source-based corporation tax with an equity allowance and a source-based cash flow tax potentially reduce the capital flight problem by exempting the normal international return to capital from tax, recognizing that this tax is likely to be shifted onto domestic immobile factors anyway. Furthermore, a destination-based cash flow tax provides no incentive to locate investment abroad rather than at home, and in its VAT type form it also avoids the problem of international profit-shifting, as we shall see. Finally, the Comprehensive Business Income Tax and the Dual Income Tax seek to address the capital flight problem by broadening the tax base to keep the tax rate low.

The following sections briefly discuss the various options for capital income tax reform summarized in Table 1. I start in section 2.2 by considering alternatives to source-based taxation, i.e., residence-based and destination-based taxes. The main rationale for these reform options is that they tend to minimise the distortionary impact of taxation on corporate location decisions. In section 2.3 I proceed to discuss alternative forms of source-based taxation which are arguably easier to implement than residence-based taxes. In both sections I consider taxes that fall on the full return to (equity) capital and taxes that fall only on rents. Throughout the discussion I am assuming that, realistically, corporate tax reforms are unlikely to be undertaken in an internationally coordinated manner. Thus I consider reforms that are carried out by one country in isolation.

\subsection{Alternatives to a source-based corporation tax}

\subsubsection{Taxing the full return to equity: a residence-based shareholder tax?}

One radical option for reform, once advocated by McLure (1979) and Feldstein (1987), might be to abolish the source-based corporate income tax altogether and to impute all of the income of a company to its shareholders, subjecting that income to the residence-based personal income tax (option 3 in Table 1). The main rationale for such a reform is that only individuals can bear a tax burden and that the impersonal corporate income tax is ill suited to achieve distributional goals. A further argument is that such full imputation of corporate income to shareholders would ensure a fully identical tax treatment of corporate and noncorporate firms and a neutral tax treatment of the different sources of investment finance (debt, retained earnings and new equity). 
Third, since a residence-based tax can be avoided only by moving abroad, and since individuals are much less mobile across borders than capital, a switch to worldwide income taxation at the personal shareholder level would greatly reduce the capital flight problem, provided that tax on foreign source income can be enforced. Finally, abolishing the whole edifice of the corporation tax might lead to considerable reductions in the costs of tax administration and compliance.

Nevertheless, there are a number of arguments against such a radical reform. For example, subjecting retained corporate profits to personal tax at the shareholder level on an accruals basis would create a liquidity problem for shareholders who receive little or no dividend from the company. Moreover, it is hardly realistic to expect that foreign corporations or foreign tax authorities would be willing to provide the information necessary to impute the retained profits of foreign companies to domestic holders of foreign shares. In the absence of an accruals-based tax on capital gains on (foreign) shares, the domestic shareholder could then defer his tax on retained profits in foreign companies until the time of realization of the shares. This would favour the holding of foreign shares relative to investment in domestic shares. To eliminate tax discrimination between domestic and foreign shares, it would be necessary to give up imputing retained profits in domestic companies to their domestic shareholders and to rely instead on a personal tax on realized capital gains on shares. However, in the absence of tax at the corporate level, this would leave a loophole in the tax system, allowing deferral of personal tax through the shifting of income into the corporate sector. The deferral advantage would also violate domestic investment neutrality and cause a 'lock-in' of capital in existing corporations by reducing the cost of capital for corporate investment financed by retained earnings.

Because of these problems, abolishing the corporation tax and imputing corporate income to shareholders is hardly a realistic reform option.

\subsubsection{Taxing the full return to equity: a residence-based corporation tax?}

As indicated above, an important function of the corporation tax is to ensure that at least some tax is levied on retained corporate profits. However, imposing tax on domestic-source corporate profits accruing to foreign investors is not necessary if the main function of the corporation tax is to serve as a backstop to the domestic personal income tax. Thus one could imagine that the corporation tax were based on a consistent residence principle where all corporations headquartered in the domestic country are taxed on their worldwide income, but where no tax is levied on domestic-source corporate profits accruing to foreign owners of corporate capital operating in the domestic economy (option 2 in Table 1). In practice the elimination of source 
taxation could be implemented by granting a credit to foreign shareholders for (their proportionate share of) any corporation tax paid by foreign-owned companies operating in the domestic country. By abolishing source taxation in this way, the incentive for inward investment by foreign investors would greatly increase. Of course, this comes at the price of giving up the revenue from the taxation of inward foreign direct investment.

To avoid international double taxation, the residence-based corporation tax could be combined with a credit for taxes paid abroad. In principle, this would ensure capital export neutrality (if the credit were given without limitation) and would eliminate the incentive for resident multinationals to invest in foreign low-tax countries rather than at home. Even if the foreign tax credit were limited to the amount of domestic tax payable on the foreign income (in line with current practice), the residence-based corporation tax would still eliminate the incentive for domestic multinationals to locate their subsidiaries in foreign tax havens.

However, company headquarters may be quite mobile internationally, so a residencebased corporation tax may not enable a country to maintain an (average) effective tax rate significantly above that prevailing in other countries, since companies can escape a high tax rate by moving their residence to a low-tax country. Moreover, it would be very hard to implement a consistent residence-based corporation tax (see Sørensen (1993)). The main problem would be the auditing of and enforcement of domestic tax on profits of foreign affiliates that are retained abroad. Like a residence-based shareholder tax, a residence-based corporation tax thus does not seem a viable reform option.

\subsubsection{Taxing rents: a destination-based cash flow business tax?}

A main argument for maintaining the corporation tax is that it serves partly as a nondistortionary tax on pure rents. If such rent capture is seen as the main function of the corporation tax, there is a case for designing it so as to leave the normal return to capital free of tax. This case is strengthened in a small open economy where capital mobility implies that a tax on the normal return to capital tends to be shifted onto the less mobile factors of production, as we explained earlier.

A cash flow tax on the real and/or financial surplus of firms allows an immediate expensing of investment. Because the present value of the cash flows from a marginal investment is just equal to the initial investment outlay, the cash flow tax therefore leaves marginal investment projects free of tax, falling only on pure rents. In a closed economy this feature would ensure that a cash flow tax would be nondistortionary. However, in an open economy the rents earned by 
multinational companies often derive from firm-specific assets and may be generated in many alternative locations. When the fixed costs of doing business are so large that multinationals choose to serve several national markets from a single location rather than producing in all countries, a cash flow tax on internationally mobile rents will therefore affect the international location decisions of multinationals, even though it will not reduce the privately optimal scale of local investment once a company has decided to locate in a particular country.

A cash flow tax on the net total of the firm's real and financial flows is essentially a dividend tax with a deduction for new share issues. In principle this tax base is more narrow than the conventional corporate tax base. In recent years most discussions of the cash flow tax have assumed that the tax would be levied on the so-called R-base which includes only cash flows from the firm's 'real' transactions, leaving out financial transactions, including interest payments. This is also the assumption made here (although it may be worth considering whether the tax base for firms in the financial service industry should include financial cash flows).

As indicated by options 7 and 8 in Table 1, there are alternative ways of designing a cash flow corporation tax in an open economy. ${ }^{19}$ One unconventional option is a VAT-type destinationbased cash flow tax. The tax base under this scheme is sales to domestic customers minus purchases from domestic suppliers and minus labour costs. Thus, export sales are not taxable, whereas all imports are taxed. Essentially the tax base is therefore equal to the current VAT base minus labour costs (assuming that the tax is levied on all firms, and not just on corporations). Because of the formal similarity with the VAT, it is possible that such a tax could get the status of an indirect tax consistent with current international tax law so that domestic tax could also be levied on the domestic sales of foreign-based firms. In that case the tax would not only fall on firms located in the domestic economy; it would also fall on firms servicing the domestic market from abroad. This is one of the attractions of the destination base: because the tax on sales to the domestic market cannot be avoided by moving production abroad, the system minimizes the incentive to relocate.

Because it allows deduction for wage costs, the VAT-type cash flow tax is basically a tax on domestic consumption out of non-wage income. Pure rents are taxed only to the extent that they are consumed by residents in the domestic jurisdiction. Hence the VAT-type cash flow tax will not

\footnotetext{
${ }^{19}$ A by now classical treatment of cash flow taxation was given by the Meade Committee (1978). Destination-based cash flow taxes were considered by Bradford (2000) and Grubert and Newlon (1997). Bond and Devereux (2002), Bradford (2004) and Zee (2006) analyse alternative cash flow taxes in an open economy.
} 
distort the investment and location decisions of firms, but at the same time it will not enable the domestic government to capture any of the rents accruing to foreigners.

A very attractive feature of the VAT-type destination-based cash flow tax is that it eliminates the transfer-pricing problem: since the proceeds of a sale to a foreign customer are not included in the tax base, the price that related companies within a multinational group use to account for an export transaction has no impact on the amount of tax paid. The same holds for an import from a related foreign party: the price set by the parties does not matter for tax purposes because there is no deduction.

On the other hand a destination-based cash flow tax raises a special transition problem: since exports are tax exempt whereas imports are taxed, the domestic-currency prices of exports have to fall (or the domestic price level has to increase) by the amount of the tax to restore equilibrium in domestic and foreign product markets. Because of short-run nominal wage and price rigidities, this adjustment process could cause considerable friction unless the exchange rate is flexible. But even if the adjustment were handled smoothly through an appreciation of the domestic currency, there would be windfall gains and losses as domestic residents with net claims on foreigners (denominated in foreign currency) would experience an erosion of the real value of these claims, whereas domestic residents with net liabilities vis á vis foreign countries would benefit from a fall in the real value of their debts. If investors dealing with foreigners anticipate the switch to the destination-based cash flow tax, they will try to rearrange their portfolios so as to reap a gain and/or to avoid a loss. The resulting capital flows could cause disruptions in capital markets and foreign exchange markets around the time of reform. Any future anticipated tax rate changes after the introduction of the tax would tend to cause similar disruptions.

Because of these problems with a destination-based tax, it seems worthwhile to consider the alternative of a source-based cash flow tax.

\subsection{Alternative source-based business tax systems}

\subsubsection{Taxing rents: a source-based cash flow business tax?}

As already mentioned, there is an efficiency case for taxing domestic location-specific rents accruing to foreigners. This may be achieved through a source-based cash flow tax where tax is levied on the net cash flow from domestic production, i.e., the cash flow from domestic and foreign sales minus the cash expenses on the purchase of domestic and imported inputs, including 
the purchase of capital goods, and minus labour costs. Such a tax will cut into all pure rents earned from domestic production.

As long as the tax does not induce companies earning mobile rents to relocate their production, the source-based cash flow tax is a nondistortionary means of shifting rents from foreigners to domestic residents (via the public budget). However, if the tax becomes too high, it will cause a shift of production out of the domestic economy. The stronger the local agglomeration forces and the better the local infrastructure, the greater is the element of location-specific rent in the total rent earned by companies, and the higher is the cash flow tax rate which may be sustained without deterring investors. Like the existing corporation tax, a source-based cash flow tax will give a tax incentive for multinationals to manipulate the transfer prices used in intra-company transactions. Indeed, compared to a traditional tax, at the same revenue, the statutory cash flow tax rate would be higher, giving greater incentive to shift profits away.

To counter the transfer-pricing problem, Bradford (2003) proposed that all cross-border real and financial cash flow transactions between related parties in a multinational group should be included in the tax base. The idea is that if, say, a parent company charges an artificially low royalty payment to its foreign subsidiary, the parent will subsequently receive a higher dividend from the subsidiary than if it had claimed an arm's length royalty. But if the dividend from the foreign affiliate is included in the tax base of the parent, any saving in the parent's tax due to understating the royalty is offset by an equal increase in tax as a result of the consequently higher dividend. In principle, the fact that the parent's tax payment is deferred is no problem under a cash flow tax which does not tax the normal return to capital, since the timing of tax payments does not matter under such a system. By contrast, under a conventional income tax deferral does generate a gain to the taxpayer. ${ }^{20}$

Introducing a cash flow tax - be it destination-based or source-based - could cause significant transition problems. ${ }^{21}$ For example, initially the tax will fall mostly on the cash flows from 'old' investment and will have the character of an (unanticipated) capital levy. This could

\footnotetext{
${ }^{20}$ To see this, suppose a taxpayer earns a capital income of 1 euro which is immediately taxed at the capital income tax rate $t$, leaving him with an after-tax income of 1-t. If he saves this income, his wealth after one year will be $X=(1-t)(1+r(1-t))$, where $r$ is the pre-tax interest rate. On the other hand, if the taxpayer can defer the tax on the initial income by one year, he can invest the full pre-tax income of 1 euro in the capital market during the year. He will then earn a net interest of $r(1-t)$ and end up with an amount of wealth equal to $Z=r(1-t)+1-t$ after payment of tax. His gain from the deferral of tax will therefore be $Z-X=\operatorname{tr}(1-t)$. This gain is positive under an income tax where $t>0$, but it is zero under a cash flow tax that effectively leaves the normal return to capital free of tax.

${ }^{21}$ The problems involved in the transition to cash flow taxation are carefully discussed by Zodrow $(2002,2003)$ and Bradford (2004).
} 
create liquidity problems for capital-intensive and heavily indebted companies, necessitating extensive grandfathering rules such as a continuation of depreciation allowances for 'old' capital and continuation of deductions for interest on 'old' debt. The more extensive the grandfathering, the smaller will be the efficiency gain from the cash flow tax.

Unanticipated tax rate changes occurring after the introduction of the cash flow tax will also generate windfall losses or gains. Moreover, a fully anticipated tax rate change could seriously disrupt the timing of investment. For example, if firms expect a future increase in the cash flow tax rate, they will postpone their investment to be able to deduct the investment expenditure against the higher future tax rate. Conversely, if they expect a future fall in the tax rate, firms will bring forward investment to take advantage of the expensing of investment against the higher current tax rate. Thus a cash flow tax with a time-varying tax rate may generate significant investment distortions and macroeconomic instability, as emphasized by Bradford (2004).

Another problem is that countries operating a foreign tax credit system may not be willing to recognize a cash flow tax as a tax eligible for foreign tax credit.

Despite the many theoretical virtues of cash flow taxation, introducing and operating a cash flow tax may thus meet with considerable practical difficulties. ${ }^{22}$

\subsubsection{Taxing rents: an Allowance for Corporate Equity?}

As an alternative to a cash flow tax, the Allowance for Corporate Equity (ACE) proposed by the Capital Taxes Group of the Institute for Fiscal Studies (1991) and by Devereux and Freeman (1991) may be a more realistic way of implementing a tax on pure rents, causing fewer transitional problems and ensuring greater conformity with current international tax law. Under the ACE system (option 6 in Table 1) companies are allowed to deduct an imputed normal return on their equity from the corporate income tax base, parallel to the deduction for interest on debt. In this way the ACE seeks to ensure neutrality between finance by debt and finance by equity. The ACE system may be combined with personal taxes on interest, dividends and capital gains, ensuring taxation of the normal return at the shareholder level.

One attractive feature of the ACE - originally pointed out by Boadway and Bruce (1984) - is that it offsets the investment distortions caused by deviations between true economic

\footnotetext{
${ }^{22}$ Nevertheless, the Estonian experience with a tax on distributed corporate profits suggests that a cash flow business tax may indeed be viable in practice. If the Estonian distribution tax were modified to allow a deduction for the revenue from new share issues, it would be equivalent to a so-called S-based cash flow tax in the terminology of the Meade Committee (1978). The Estonian business tax experiment is reviewed in Devereux and Sørensen (2005, pp. 44-46).
} 
depreciation and depreciation for tax purposes. For example, if firms write down their assets at an accelerated pace, the current tax saving from accelerated depreciation will be offset by a fall in future rate-of-return allowances of equal present value, since accelerated depreciation reduces the book value of the assets to which future rates of return are imputed. In fact, regardless of the rate at which firms write down their assets in the tax accounts, the present value of the sum of the capital allowance and the ACE allowance will always equal the initial investment outlay, so the ACE system is equivalent to the immediate expensing of investment allowed under a cash flow tax.

Another attraction of the ACE is that the symmetric treatment of debt and equity eliminates the need for thin capitalization rules to protect the domestic tax base: since firms get a deduction for an imputed interest on their equity as well as for the interest on their debt, multinationals have no incentive to undercapitalize a subsidiary operating in a country with an ACE system.

The neutrality properties of the ACE system will depend on whether the imputed rate of return on equity is set at the 'right' level. In principle it is not necessary to include a risk premium in the imputed rate of return, provided the tax reduction stemming from the ACE allowance is a 'safe' cash flow from the viewpoint of the firm (see Bond and Devereux (1995)). This requires full loss offsets, including unlimited carry-forward of losses with interest. With limitations on loss offsets, the imputed return should include a risk premium, but in practice the tax authorities would not have the firm-specific information necessary to choose the 'correct' risk premium. Hence some distortion of the pattern of investment and risk taking would be unavoidable under incomplete loss offsets. $^{23}$

Like a cash flow tax, the ACE system is a tax on pure rents. Such a tax inevitably imposes a higher average tax rate on highly profitable firms than on less profitable firms (indeed, firms earning only normal returns go free of tax). In the context of an open economy where firms earn mobile rents, this may be a problematic feature of the ACE system if policy makers raise the corporate tax rate to offset the revenue loss caused by the introduction of the ACE allowance. In that case the transition to the ACE system will raise the relative and absolute tax burden on the most profitable firms, possibly inducing them to relocate abroad, and leaving the domestic economy with the less profitable (and hence presumably the less dynamic) firms, as pointed out by Bond (2000).

\footnotetext{
${ }^{23}$ In particular, many small businesses may be credit-constrained and may therefore have a higher cost of equity finance than large companies with easier access to capital markets, but in practice the deductible imputed cost of equity finance would probably have to be the same for all firms.
} 
Moreover, in so far as transition to an ACE requires a rise in the statutory tax rate, it will increase the country's vulnerability to outward profit-shifting via transfer-pricing.

However, these are general points about all taxes on rents, and are not a particular weakness of the ACE system. Indeed, the ACE shares several strengths and weaknesses with other rent taxes such as the various cash flow taxes. On the positive side, both the ACE and the cash flow taxes eliminate distortions due to deviations between true economic depreciation and depreciation for tax purposes, and both types of taxes are in principle neutral towards corporate financing decisions. On the negative side, by exempting normal returns from tax, rent taxes tend to require higher statutory tax rates to secure the desired revenue. This is likely to deter inward investment by highly profitable multinationals and to provoke outward profit-shifting through transfer-pricing.

One important difference between the ACE and cash flow taxation is that anticipated tax rate changes may cause serious distortions to the timing of investment under the latter tax system, as we explained in the previous section. Introducing cash flow taxation is also likely to cause more significant transition problems. On the other hand, we noted that in practice it may be difficult to set the imputed cost of equity finance at the 'right' level under the ACE. ${ }^{24}$

\subsubsection{Taxing the full return to capital: the Comprehensive Business Income Tax}

The ACE aims at tax neutrality between equity and debt by allowing a deduction for the (opportunity) cost of equity as well as debt. The so-called Comprehensive Business Income Tax (CBIT) proposed by the U.S. Treasury in 1992 also seeks to end the tax discrimination in favour of debt finance, but it does so by eliminating the deductibility of interest payments. ${ }^{25}$ The aim of the CBIT proposal was to secure a single uniform tax on all corporate source income at a rate (roughly) equal to the top marginal personal tax rate on capital income. In this way the CBIT would in principle make personal taxes on corporate source income redundant, given the Treasury's goal of ending the classical double taxation of such income.

Given the practical problems of enforcing residence-based personal taxes on interest income and the prevalence of tax-exempt institutional investors investing in debt instruments, it seems realistic to assume that a large part of total interest income currently goes untaxed in most countries. By essentially introducing an interest income tax at source, the CBIT might therefore

\footnotetext{
${ }^{24}$ Interestingly, Croatia has tested an ACE in practice. The Croatian experience is reviewed in Rose and Wiswesser (1998) and Keen and King (2002).

${ }^{25}$ The Comprehensive Business Income Tax is described and discussed in the report of the U.S. Treasury (1992). Bond (2000) discusses the pros and cons of the ACE versus the CBIT.
} 
imply a significant increase in the cost of debt finance. Clearly this could act as a strong deterrent to debt-financed inward investment. On the other hand the broadness of the CBIT tax base would allow a relatively low corporate tax rate, for any given amount of revenue collected. The low statutory tax rate would imply a relatively low average effective tax rate on highly profitable companies. If the same amount of business tax revenue had to be collected under an ACE system, a higher statutory tax rate would be needed, so despite the non-deductibility of interest under the CBIT, this tax system might well be more attractive for high-yielding companies than the ACE. Since highly profitable companies are often high-tech multinationals generating significant positive externalities in the host country of investment, a small open economy may prefer the CBIT to the ACE because the former system may generate more inward investment with positive spillovers on the domestic economy.

On the other hand, the CBIT and the ACE may be seen as alternative methods of eliminating the classical double taxation of corporate equity income, so if the revenue from the $\mathrm{CBIT}$ is required to compensate for the loss of revenue from personal taxes on dividends and capital gains on shares, there is less scope for lowering the statutory corporate tax rate under this tax system. Still, since part of the shares in domestic companies are held by foreigners and by taxexempt institutional investors, alleviating double taxation at the corporate level - as is done under the ACE - will almost surely involve a greater revenue loss than double tax relief at the domestic personal shareholder level.

The effects of a revenue-neutral transition from a classical corporate tax system to the CBIT may thus be summarized as follows: for low-yielding companies relying mostly on debt, the cost of capital could rise significantly, but for high-yielding companies relying mainly on equity the overall cost of capital would most likely fall.

However, the assumption of revenue-neutrality may be unrealistic: to prevent too many bankruptcies as a result of the transition to a CBIT with no deduction for interest payments, it would probably be necessary to apply a rather low corporate tax rate under this tax system. Since the CBIT proposal also abolishes personal taxes on shareholder income, the reform might lead to a non-negligible revenue loss, given the need for a low corporate tax rate.

\subsubsection{Taxing the full return to capital: the dual income tax}

As noted in section 1.4, the theoretical case for a zero tax rate on the normal return to capital is not clear-cut, and despite the policy inconsistencies alluded to in section 1.6, most 
governments apparently prefer to maintain some amount of tax on normal returns, including returns accruing to foreigners. However, the international mobility of capital and the opportunities for international profit-shifting impose a tight constraint on the level of source-based corporate taxes that can be sustained in a small open economy in the absence of international tax coordination. Hence it will be optimal to keep the source-based corporate tax rate fairly low in a small open economy, especially in a 'peripheral' country where business does not benefit from significant agglomeration forces. For revenue and distributional reasons it will therefore typically be necessary to have a top marginal tax rate on labour income which is significantly higher than the corporate tax rate.

Some years ago the Nordic countries decided to make a virtue out of this necessity by introducing the so-called Dual Income Tax (option 4 in Table 1). ${ }^{26}$ The Dual Income Tax (DIT) imposes a low flat uniform tax rate on all income from capital (including corporate income) and applies a progressive tax schedule to labour income. In the pure version of the system, the tax rate in the lowest bracket of the schedule for labour income is aligned with the capital income tax rate so that only labour income above a certain level is taxed at a higher rate. Thus the DIT may also be described as a combination of a proportional tax on all income and a progressive surtax on high labour income. The flatness and uniformity of the capital income tax may be seen as an attempt to achieve the greatest possible degree of neutrality in a tax system that attempts to tax the full return to capital.

An interesting version of the DIT was the tax system prevailing in Norway from 1992 until the end of 2005. Under this system the double taxation of corporate source equity income was fully alleviated. For dividends this was done through an imputation system, and for capital gains it was achieved through the so-called RISK system which allowed the shareholder to write up the basis of his shares with (his proportionate amount of) the retained profit which had already been subjected to corporation tax. Thus the personal capital gains tax was imposed only on (realized) income that had not already been taxed at the corporate level. Because all capital income was taxed uniformly and business income was taxed only once, the Norwegian DIT was in principle neutral towards investment and financing decisions.

\footnotetext{
${ }^{26}$ The rationale for the Nordic Dual Income Tax is explored in Sørensen (1994, 2005b) and Nielsen and Sørensen (1997). Sijbren Cnossen's preferred version of the system is described in Cnossen (2000). Elements of dual income taxation have been introduced in several European countries; see the survey by Eggert and Genser (2004). Recently variants of a dual income tax for Germany have been proposed by Sinn (2003, ch. 6$)$ and by the German Sachverständigenrat (see Spengel and Wiegard (2004), and Wiegard et al. (2006)). Keuschnigg and Dietz (2005) propose a 'Swiss Dual Income Tax' which essentially combines the ACE with the new Norwegian shareholder income tax described in the next subsection.
} 
However, since labour income is taxed more heavily than income from capital, a DIT gives the taxpayer an incentive to relabel his labour income as capital income. This option is mainly open to (controlling) owners of small firms who work in their own business. To prevent such income shifting, the previous Norwegian tax rules required that the income of the self-employed and of 'active' owners of corporations be split into a capital income component and a labour income component. The capital income component was calculated as an imputed return on the value of the business assets in the firm's tax accounts. The residual business profit was then taxed as labour inome (up to a certain ceiling beyond which the profit was again categorized as capital income). ${ }^{27}$

Since the capital income tax is flat and uniform across all taxpayers, the DIT allows taxes on corporate source income to be collected as withholding taxes at the corporate level, as under the Comprehensive Business Income Tax. In practice, the Nordic countries reduce withholding taxes on interest and dividends paid to foreign residents in accordance with bilateral double tax treaties.

To make the enforcement of tax on interest income more effective in an open economy context, Cnossen (2000) has proposed that the DIT be combined with a withholding tax on interest income paid out to foreign (personal and corporate) investors, levied at the same rate as that applying to all other domestic-source capital income. This would move the DIT closer to the source-based CBIT (which is why the two tax systems are placed in the same box in Table 1). While the Cnossen proposal would reduce the current tax advantage to debt finance (arising from ineffective enforcement of tax on interest income), it would for the same reason increase the cost of debt finance and could potentially lead to a capital flight if implemented unilaterally by a small open economy. The discouraging German experience with a withholding tax on interest in the early 1990s suggests that it is very difficult for a single country to impose even a low withholding tax on interest at source.

\subsubsection{Reinventing the Dual Income Tax: the 2006 Norwegian tax reform}

As noted above, a Dual Income Tax requires a system of mandatory income splitting for small firms. In Norway this system has worked reasonably well for the self-employed, but not for so-called active owners of small companies. Under the Norwegian tax rules prevailing until the end of 2005, a shareholder was deemed to be 'active' and hence liable to income splitting if he

\footnotetext{
27 The problems of income splitting under the dual income tax are discussed in more detail in Hagen and Sørensen (1998) and Sørensen (2005b).
} 
carried out some minimum amount of work in the company and controlled at least two thirds of the shares (alone or together with his closest relatives). However, by inviting 'passive' owners into the company, many Norwegian owner-managers were able to avoid mandatory income splitting and to have all of their income taxed at the low capital income tax rate even when a substantial part of the income was in fact labour income. Indeed, the number of small companies subject to mandatory income splitting was steadily falling since the introduction of the DIT in 1992, so this part of the Norwegian tax system turned out to be its Achilles heel.

Because of these problems with the income splitting system, the Norwegian parliament recently passed a tax reform bill that took effect from 2006, following recommendations from an expert committee. The reform replaced the problematic income splitting system for 'active' shareholders by a so-called shareholder income tax (in Norwegian: 'aksjonærmodellen'). This is a personal residence-based tax levied on that part of the taxpayer's realized income from shares (dividends plus realized capital gains) which exceeds an imputed after-tax rate of interest on the basis of his shares. As demonstrated in Sørensen (2005a), the shareholder income tax will in principle be neutral, since it exempts the normal (risk free) return from tax. Shareholder income in excess of the imputed normal return is supposed to be taxed as ordinary capital income. At the margin, the total corporate and personal tax burden on corporate equity income will be roughly equal to the top marginal tax rate on labour income. Hence corporate owner-managers will gain nothing by transforming labour income into dividends and capital gains, allowing the abolition of the mandatory income splitting system for active shareholders.

To avoid discrimination against investment in foreign shares, the rate-of-return allowance (RRA) under the shareholder income tax will be granted to holders of foreign as well as Norwegian shares. Compared to the present situation where no double tax relief is offered to holders of foreign shares, the RRA will give Norwegian taxpayers an incentive to report their foreign shareholdings.

The new Norwegian shareholder income tax is not just a new technical solution to the problem of splitting business income into labour income and capital income; it also reflects a change in the philosophy underlying the DIT. Under the previous Norwegian version of the DIT the full return to corporate capital was taxed as capital income. Under the new Norwegian shareholder income tax the low capital income tax rate will apply only to an imputed risk-free rate of interest on the value of the shareholding, whereas all realized shareholder income in excess of the risk-free return will be taxed at (roughly) the high marginal rate applying to labour income. In other words, 
the equity premium will be taxed as earned income. If the realized income from shares falls short of the imputed risk-free rate of return (the RRA) in some year, the unutilized RRA may be deducted from the base of the shareholder income tax in subsequent years and may also be added to the basis of the share. In this way unutilized RRAs are effectively carried forward with interest so as to ensure neutrality of the shareholder income tax (see Sørensen (2005a) for a formal treatment). A highly interesting feature of the shareholder income tax is that, although capital gains on shares are taxed only when they are realized, the RRA will ensure that realization decisions are not distorted by the tax, as proved in Sørensen (2005a). Indeed, the shareholder income tax satisfies the properties of the retrospective capital gains tax proposed by Auerbach (1991) and the generalized cash flow tax described by Auerbach and Bradford (2001); i.e., tax designs that are known to be neutral towards realization decisions even though they do not involve taxation of unrealized gains.

It still remains to be seen whether the new Norwegian shareholder income tax will provide a satisfactory solution to the problem of income shifting under the DIT. However, it should be noted that this problem is not specific to the Dual Income Tax. In most OECD countries the existence of social security taxes implies that the marginal effective tax rate on labour income often exceeds the marginal tax rate on capital income by a considerable margin. In all such cases taxpayers will have an incentive to try to relabel labour income as capital income.

\section{PART 3. SUMMING UP AND COMPARING ALTERNATIVE BLUEPRINTS FOR CAPITAL INCOME TAX REFORM}

In Part 2 I have tried to provide a balanced overview of the pros and cons relating to a number of proposals for fundamental capital income tax reform that have been prominent in the international tax policy debate in recent decades. Table 2 below attempts to summarize how the various blueprints for reform address the concerns of policy makers, that is, the extent to which they eliminate or reduce the most important distortions caused by existing corporate tax systems.

In principle, the ACE, the CBIT, the DIT, the residence-based shareholder tax and the different variants of the cash flow tax all eliminate the tax distortions to the choice between debt and equity and between new equity and retained earnings. The ACE and the cash flow tax do so by exempting the normal return to capital from tax, whether it takes the form of interest on debt or whether it accrues as a return to corporate equity. By contrast, the CBIT and the DIT (in the variant 
Table 2. Distortions addressed by

\section{alternative proposals for capital income tax reform}

\begin{tabular}{|c|c|}
\hline Distortion to & Reform proposal addressing distortion \\
\hline Choice between debt and equity & $\begin{array}{l}\text { ACE, Cash flow tax, CBIT, DIT, } \\
\text { Residence-based shareholder tax }\end{array}$ \\
\hline $\begin{array}{l}\text { Choice between new equity } \\
\text { and retained earnings }\end{array}$ & $\begin{array}{l}\text { ACE, Cash flow tax, CBIT, DIT, } \\
\text { Residence-based shareholder tax }\end{array}$ \\
\hline Choice of organizational form & $\begin{array}{l}\text { ACE, Cash flow tax, CBIT, DIT*, } \\
\text { Residence-based shareholder tax }\end{array}$ \\
\hline Domestic real investment & ACE, Cash flow tax \\
\hline $\begin{array}{l}\text { International location } \\
\text { of real investment }\end{array}$ & $\begin{array}{l}\text { Residence-based shareholder tax, } \\
\text { Residence-based corporate income tax*, } \\
\text { VAT-type destination-based cash flow tax }\end{array}$ \\
\hline $\begin{array}{l}\text { International location } \\
\text { of tax base }\end{array}$ & $\begin{array}{l}\text { Residence-based shareholder tax, } \\
\text { Residence-based corporate income tax*, } \\
\text { VAT-type destination-based cash flow tax }\end{array}$ \\
\hline
\end{tabular}

* This reform proposal only partially alleviates the distortion mentioned.

$\mathrm{ACE}=$ Allowance for Corporate Equity $\mathrm{CBIT}=$ Comprehensive Business Income Tax; DIT = Dual Income Tax. 
proposed by Cnossen (2000)) achieve financial neutrality by taxing all returns to debt and equity at the corporate level and at the same uniform rate, and the residence-based shareholder tax eliminates the corporate tax distortion to financial choices by simply abolishing the corporation tax.

Proponents of the CBIT and the cash flow tax have presented these tax systems as blueprints for a general business tax, to be applied to corporate and non-corporate firms alike. Furthermore, although the ACE was originally proposed as a model for corporate tax reform, there is no reason why it could not be extended to all types of firms. When applied across the board, the CBIT, the cash flow tax and the ACE thus ensure tax neutrality with regard to the choice of organizational form. ${ }^{28}$ The DIT also strives to achieve neutrality between the corporate and non-corporate sector by alleviating the double taxation of the (normal) return to corporate equity. However, since corporate and non-corporate firms are not subject to quite the same tax rules, the DIT probably does not achieve full tax neutrality across different types of firms, as indicated by the asterisk in Table $2^{29}$

Once companies have made a decision on their international location, the ACE and the cash flow tax ensure that decisions regarding the scale of investment are left undistorted by taxation. The reason is that both types of tax imply a zero marginal effective tax rate, driving no wedge between the international cost of finance and the required pre-tax return on investment. Hence the statement in Table 2 that these tax systems eliminate the distortion to domestic real investment. By contrast, source-based taxes that include the normal return to capital in the tax base will cause the required pre-tax rate of return to deviate from the international cost of finance. Residence-based taxes will also be distortionary unless depreciation for tax purposes happens by chance to equal the true economic depreciation of the asset. For these reasons only the ACE and the cash flow tax are claimed to be neutral towards domestic investment in Table 2 .

In so far as a consistent residence-based shareholder tax can be administered (involving full imputation of domestic and foreign source corporate income to individual shareholders), it will be neutral towards the international location of corporate investment, as long as shareholders maintain their residence. Thus the international tax policy game would change from the current fierce competition to attract highly mobile corporate capital to a competition to attract the less mobile

\footnotetext{
${ }^{28}$ The benefits from neutrality in this dimension may be non-negligible. For example, using data for the period 19591986, Gordon and Mackie-Mason (1997) estimated that the deadweight loss from tax distortions to the choice of organizational form in the US amounted to 16 percent of total business tax revenue.

${ }^{29}$ Under the new Norwegian tax system that took effect from 2006, the owners of companies are subject to the new shareholder income tax, whereas proprietors will continue to be taxed under a streamlined version of the previous income splitting system.
} 
individual shareholders. However, we also noted that implementing a residence-based system of full imputation and doing away with the corporation tax would most likely meet with insurmountable practical difficulties. A consistent residence-based corporate income tax with an unlimited foreign tax credit is arguably easier to implement, but it is vulnerable to the fact that corporate headquarters can be quite mobile. In practice this reform option is therefore unlikely to ensure full neutrality with regard to the international location of investment, as suggested by the asterisk in Table 2 . In principle, a destination-based cash flow tax ensures neutrality towards location decisions, but as we explained in section 2.2.3, this tax regime involves special transition problems relating to residents with net foreign assets or liabilities.

To the extent that it can be implemented, a consistent residence-based tax will solve the problem of international profit-shifting via transfer-pricing and thin capitalization, since companies and/or their owners will gain nothing from shifting corporate profit from domestic to foreign entities within a multinational group. But again, enforcing the residence principle is a daunting task. In comparison, a destination-based cash flow tax of the VAT type could surely be administered after all, most OECD countries are already running a VAT system - but it does raise transition problems as well as the problem that anticipated tax rate changes might seriously distort the timing of investment.

Because they treat debt and equity finance alike, the ACE, the cash flow tax, the CBIT and the source-based DIT proposed by Cnossen (2000) all eliminate the problem of international profitshifting though thin capitalization. However, the standard transfer-pricing problem remains with all of these systems, and it is likely to be exacerbated under the ACE and under the cash flow tax, because these tax regimes will tend to require a higher statutory tax rate, given that tax is levied only on rents.

The basic message from this discussion is that governments are faced with trade-offs in multiple dimensions. For example, according to Table 2 the move to a destination-based cash flow tax of the VAT type - that is, a tax on domestic consumption out of non-wage income - would in principle eliminate all the important distortions on which policy-makers have tended to focus. However, this is achieved only through a radical departure from current tax practices, i.e., by giving up the taxation of normal returns to capital ${ }^{30}$ and the taxation of domestic-source income accruing to foreigners.

\footnotetext{
${ }^{30}$ In principle, of course, it would still be possible to combine a business tax on pure profits with a personal income tax on interest, dividends and capital gains to ensure some amount of tax on normal returns.
} 
As another example, while rent taxes like the ACE and the cash flow tax achieve neutrality in many important dimensions, they also tend to increase the transfer-pricing problem by making it harder to keep the statutory tax rate low. And while the CBIT and the source-based DIT do in principle allow a low statutory rate because these taxes are levied on a broad base, in practice a source-based tax on the normal return (especially a source tax on interest) is likely to exacerbate the problem of capital flight.

From a practical administrative viewpoint, the ACE and the DIT seem easier to implement than the other reform options considered here. Indeed, both of these tax systems have already been tested in practice. The fundamental policy decision to make when choosing between these two alternatives is whether a business tax should tax the normal return to capital or not.

In an uncertain world, it is some comfort to be able to make one safe prediction: the controversy over capital income taxation will continue!

\section{REFERENCES}

Aiyagari, S.R. (1993). "Optimal capital income taxation with incomplete markets, borrowing constraints, and constant discounting." Journal of Political Economy 103, 1158-1175.

Atkinson, A.B. and J. E. Stiglitz (1976). "The design of tax structure: Direct versus indirect taxation." Journal of Public Economics 6, 55-75.

Auerbach, A. (1991). "Retrospective capital gains taxation." American Economic Review 81, $167-$ 178.

Auerbach, A. and D. Bradford (2004). "Generalized cash flow taxation.” Journal of Public Economics 88, 957-980.

Bacchetta, P. and M.P. Espinosa (2000). "Exchange-of-Information Clauses in International Tax Treaties." International Tax and Public Finance 7, 275-293.

Baldwin, R. and P. Krugman (2002). “Agglomeration, integration and tax harmonization.” NBER Working Paper 9290.

Baldwin, R., R. Forslid, P. Martin, G. Ottaviano and F. Robert-Nicoud (2003), Economic Geography and Public Policy, Princeton University Press.

Barro, R.J. (1974). “Are government bonds net wealth?” Journal of Political Economy 82, 10951117. 
Becker, J. and C. Fuest (2005), "Does Germany collect revenue from taxing the normal return to capital?" Fiscal Studies 26, 491-511.

Bernheim, B.D. (2002). “Taxation and saving”, in: A. Auerbach and M.S. Feldstein (eds.), Handbook of Public Economics, Vol. 3, Chapter 18, North-Holland: Elsevier.

Boadway, R. and N. Bruce (1984). "A general proposition on the design of a neutral business tax", Journal of Public Economics 24, 231-239.

Boadway, R. and N. Bruce (1992). "Problems with integrating corporate and personal income taxes in an open economy." Journal of Public Economics 48, 39-66.

Bond, S.R. (2000). "Levelling up or levelling down? Some reflections on the ACE and CBIT proposals, and the future of the corporate tax base." In S. Cnossen (ed.), Taxing Capital Income in the European Union - Issues and Options for Reform, Oxford University Press, Oxford.

Bond, S.R. and M.P. Devereux (1995). "On the design of a neutral business tax under uncertainty." Journal of Public Economics 58, 57-71.

Bond, S.R. and M.P. Devereux (2002). "Cash flow taxes in an open economy." CEPR Discussion Paper No. 3401.

Bottazzi, L., P. Pesenti and E. van Wincoop (1996). "Wages, profits and the international portfolio puzzle.” European Economic Review 40, 219-254.

Bovenberg, A.L. and B. Jacobs (2005a). "Human capital and optimal positive taxation of capital income.” CEPR Discussion Paper No. 5047, May 2005.

Bovenberg, A.L. and B. Jacobs (2005b). "Redistribution and education subsidies are Siamese twins." Journal of Public Economics 89, 2005-2035.

Bradford, D. (2000). "Blueprint for international tax reform." Brooklyn Journal of International Law XXVI-4, 1449-1463.

Bradford, D. (2003). "Addressing the transfer-pricing problem in an origin-basis X tax." International Tax and Public Finance 10, 591-610.

Bradford, D. (2004). “The X tax in the world economy.” CESifo Working Paper No. 1264.

Chamley, C. (1986). "Optimal taxation of capital income in general equilibrium with infinite lives." Econometrica 54, 607-22.

Chamley, C. (2001). "Capital income taxation, wealth distribution and borrowing constraints." Journal of Public Economics 79, 55-69. 
Cnossen, S. (2000). "Taxing capital income in the Nordic countries: a model for the European Union?" In S. Cnossen (ed.), Taxing Capital Income in the European Union - Issues and Options for Reform, Oxford University Press, Oxford.

Corlett, W. and D. Hague (1953). "Complementarity and the excess burden of taxation." Review of Economic Studies 21, 21-30.

Devereux, M.P. and H. Freeman (1991). “A general neutral profits tax.” Fiscal Studies 12, 1-15.

Devereux, M.P. and P.B. Sørensen (2005). "The corporate income tax: international trends and options for fundamental reform”. EPRU Analysis No. 24, Economic Policy Research Unit, Department of Economics, University of Copenhagen.

Eggert, W. and B. Genser (2005). "Dual income taxation in EU member countries." CESifo DICE Report 3 (1), 41-47.

Eggert, W. and A. Haufler (2006). "Company tax coordination cum tax rate competition in the European Union.” Mimeo, University of Paderborn and University of Munich, March 2006.

Eggert, W. and M. Kolmar (2002). "Residence-based capital taxation in a small open economy: why information is voluntarily exchanged and why it is not." International Tax and Public Finance 9, 465-482.

Feldstein, M. (1987). "Imputing corporate tax liabilities to individual shareholders." NBER Working Paper No. 2349.

French, K. and J. Poterba (1993). "Investor diversification and international equity markets." In R. Thaler (ed.), Advances in Behavioral Finance, New York: Russel Sage Foundation.

Fuest, C. and B. Huber (2000). "Can corporate-personal tax integration survive in open economies?” FinanzArchiv 57, 514-24.

Fuest, C. and A. Weichenrieder (2002). "Tax competition and profit shifting: on the relationship between personal and corporate tax rates." CESifo Working Paper No. 781.

Gordon, R. (1986), Taxation of investment and savings in a world economy, American Economic Review 76, 1086-1102.

Golosov, M., N. Kocherlakota and A. Tsyvinski (2003). "Optimal indirect and capital taxation." Review of Economic Studies 70, 569-587.

Gordon, R. (1992). "Can capital income taxes survive in open economies?" Journal of Finance 47, 1159-1180.

Gordon, R. (2000). "Taxation of capital income versus labor income: an overview". In S. Cnossen (ed.), Taxing Capital Income in the European Union - Issues and Options for Reform, Oxford University Press, Oxford.

Gordon, R. and A.L. Bovenberg (1996). "Why is capital so immobile internationally? Possible 
explanation and implications for capital income taxation." American Economic Review 86, 10571075.

Gordon, R. and J.R. Hines (2002). “International taxation.” In A. Auerbach and M. Feldstein (eds.), Handbook of Public Economics IV, North-Holland, Chapter 28.

Gordon, R., L. Kalambokidis, and J. Slemrod (2004). "Do we now collect any revenue from taxing capital income?” Journal of Public Economics 88, 981-1009.

Gordon, R. and Y. Lee (2001). "Do taxes affect corporate debt policy? Evidence from U.S. corporate tax return data." Journal of Public Economics 82, 195-224.

Gordon, R. and J. Mackie-Mason (1994). "Tax distortions to the choice of organizational form." Journal of Public Economics 55, 279-306.

Gordon, R. and J. Slemrod (1988). "Do we collect any revenue from taxing capital income?" In L. Summers (ed.), Tax Policy and the Economy 2, Cambridge, MA: MIT Press.

Gordon, R.H. and J.K. Mackie-Mason (1997). "How much do taxes discourage incorporation?" The Journal of Finance 52, 477-505.

Gordon, R. and H. Varian (1989). "Taxation of asset income in the presence of a world securities market.” Journal of International Economics 26, 205-226.

Grubert, H. and T.S. Newlon (1997). Taxing Consumption in a Global Economy. Washington, D.C.: American Enterprise Institute.

Hagen, K.P. and P.B. Sørensen (1998). "Taxation of income from small businesses: Taxation principles and tax reforms in the Nordic countries." In P.B. Sørensen (ed.), Tax Policy in the Nordic Countries, Macmillan Press, London.

Hartman, D. (1985). "Tax policy and foreign direct investment." Journal of Public Economics 26, 107-121.

Haufler, A. and G. Schjelderup (2000). "Corporate tax systems and cross country profit shifting." Oxford Economic Papers 52, 306-325.

Hines, J. R. (1999). "Lessons from behavioural responses to international taxation." National Tax Journal 52, 305-322.

Huizinga, H. and G. Nicodéme (2003). "Foreign ownership and corporate taxation: an empirical investigation.” CEPR Discussion Paper No. 3952.

Huizinga, H. and S.B. Nielsen (1997). "Capital Income and Profits Taxation with Foreign Ownership of Firms.” Journal of International Economics 42, 149-165.

Huizinga, H. and S.B. Nielsen (2003). "Withholding taxes or information exchange: the taxation of international interest flows." Journal of Public Economics 87, 39-72. 
Institute for Fiscal Studies (1991). Equity for Companies: A Corporation Tax for the 1990s.

London.

Judd, K. (1985). "Redistributive taxation in a simple perfect foresight model." Journal of Public Economics 28, 59-83.

Keen, M. and J. Ligthart (2006). "Incentives and information exchange in international taxation." International Tax and Public Finance 13, 163-180.

Keen, M. and J. King (2002). "The Croatian profit tax: an ACE in practice." Fiscal Studies 23, 401418.

Keuschnigg, C. and M. Dietz (2005). "A growth-oriented dual income tax.” CESifo Working Paper No. 1513.

Kind, H.J., K.H. Midelfart Knarvik and G. Schjelderup (2000). "Competing for capital in a lumpy world." Journal of Public Economics 78, 253-274.

King. M.A. (1974). "Taxation, investment and the cost of capital." Review of Economic Studies, 41, 21-35.

King, M.A. and D. Fullerton (1984). The Taxation of Income from Capital. Chicago: University of Chicago Press.

Krusell, P., L. Ohanian, J.-V. Rios Rull, and G. Violante (2000). "Capital-skill complementarity and inequality: A macroeconomic analysis." Econometrica 68, 1029-53.

Lindquist, M. (2005). “Capital-skill complementarity and inequality in Sweden.” Scandinavian Journal of Economics 107, 711-736.

McLure, C.E. (1979). Must Corporate Income Be Taxed Twice? Washington: The Brookings Institution.

Meade, J. (1978). The Structure and Reform of Direct Taxation. London: Allen and Unwin.

Mintz, J. (1994). "Is there a future for capital income taxation?" Canadian Tax Journal 42, 14691503.

Mintz, J. (1995). “The corporation tax: a survey.” Fiscal Studies 16, 23-68.

Nielsen, S.B. and P.B. Sørensen (1997). "On the optimality of the Nordic system of dual income taxation." Journal of Public Economics 63, 311-329.

Ordover, J. and E. Phelps (1979). "The concept of optimal taxation in the overlapping generations model of capital and wealth." Journal of Public Economics 12, 1-26. 
Razin, A. and E. Sadka (1991). "International tax competition and gains from tax harmonization." Economics Letters 37, 69-76.

Rose, M. and R. Wiswesser (1998). "Tax reform in transition economies: experiences from the Croatian tax reform process of the 1990s." In P.B. Sørensen (ed.), Public Finance in a Changing World, Basingstoke: Macmillan.

Salanié, B. (2003). The Economics of Taxation. MIT Press.

Sinn, H.-W. (2003). Ist Deutschland noch zu retten? Berlin: Econ Verlag.

Spengel, C. and W. Wiegard (2004). "Dual income tax: a pragmatic reform alternative for Germany." CESifo DICE Report 2 (3), 15-22.

Sørensen, P.B. (1988). "Wealth taxation, income taxation, and savings". Blue Mimeo 163, Department of Economics, University of Copenhagen.

Sørensen, P.B. (1993). "Co-ordination of capital income taxation in the Economic and Monetary Union: What needs to be done?" In F. Giavazzi and F. Torres (eds.), Adjustment and Growth in the European Monetary Union, CEPR and Cambridge University Press.

Sørensen, P.B. (1994). "From the global income tax to the dual income tax - Recent tax reforms in the Nordic countries." International Tax and Public Finance 1, 57-79.

Sørensen, P.B. (2000). “The case for international tax coordination reconsidered." Economic Policy $31,429-472$.

Sørensen, P.B. (2001). "Tax coordination in the European Union: What are the issues?" Swedish Economic Policy Review 8, Winter 2001.

Sørensen, P.B. (2004a). “International tax coordination: regionalism versus globalism?” Journal of Public Economics 88, 1187-1214.

Sørensen, P.B. (2004b). “Company tax reform in the European Union”. International Tax and Public Finance 11, 91-115.

Sørensen, P.B. (2005a). "Neutral taxation of shareholder income." International Tax and Public Finance 12, 777-801.

Sørensen, P.B. (2005b). "Dual income taxation - Why and how?” FinanzArchiv 61, 559-586.

Sørensen, P.B. (2005c). "Taxation of shareholder income and the cost of capital in an open economy - Theory and applications to the Nordic countries." Danish Journal of Economics 143, 433-447.

Sørensen, P.B. (ed., 2004). Measuring the Tax Burden on Capital and Labor. CESifo Seminar Series, Cambridge, MA: MIT Press. 
Tanzi, V. and H. Zee (2001). "Can information exchange be effective in taxing cross-border income flows?”. In K. Andersson, P. Melz and C. Silfverberg (eds.), Modern Issues in the Law of International Taxation, Stockholm: Kluwer Law International.

U.S. Treasury (1992). Integration of the Individual and Corporate Tax Systems - Taxing Business Income Once. Washington, D.C.

Westerhout, E. (2002). "The capital tax and welfare effects from asymmetric information on equity markets.” International Tax and Public Finance 9, 219-233.

Wiegard, W., W. Schön, U. Schreiber and C. Spengel (2006). Reform der Einkommens- und Unternehmensbesteuerung durch die Duale Einkommensteuer. Joint report by the Sachverständigenrat zur Begutachtung der gesamtwirtschaftlichen Entwicklung, Max-PlanckInstitut für Geistiges Eigentum, Wettbewerbs- und Steuerrecht, und Zentrum für Europäische Wirtschaftsforschung, Wiesbaden, April 2006.

Wildasin, D. (2000). "Factor mobility and fiscal policy in the EU: policy issues and analytical approaches”. Economic Policy 31, 337-378.

Zodrow, G. (2002). "Transitional issues in the implementation of a Flat Tax or a National Retail Sales Tax." In G. Zodrow and P. Mieszkowski (eds.), United States Tax Reform in the 21st Century. Cambridge University Press, Cambridge.

Zodrow, G. (2003). "Prospects for consumption-based tax reform in the United States." FinanzArchiv 59, 264-294.

Zodrow, G. (2006). "Capital mobility and source-based taxation of capital income in small open economies". International Tax and Public Finance 13, 269-294. 